\title{
Interleukin-1, tumor necrosis factor-alpha, and transforming growth factor-beta 1 and integrative meniscal repair: influences on meniscal cell proliferation and migration
}

Katherine M Riera', Nicole E Rothfusz ${ }^{1,2}$, Rebecca E Wilusz ${ }^{1,2}$, JB Weinberg ${ }^{3,4}$, Farshid Guilak ${ }^{1,2^{*}}$ and Amy L McNulty ${ }^{1}$

\begin{abstract}
Introduction: Interleukin-1 (IL-1) and tumor necrosis factor- $\alpha$ (TNF- $\alpha$ ) are up-regulated in injured and osteoarthritic knee joints. IL-1 and TNF- $\alpha$ inhibit integrative meniscal repair; however, the mechanisms by which this inhibition occurs are not fully understood. Transforming growth factor- $\beta 1$ (TGF- $\beta 1$ ) increases meniscal cell proliferation and accumulation, and enhances integrative meniscal repair. An improved understanding of the mechanisms modulating meniscal cell proliferation and migration will help to improve approaches for enhancing intrinsic or tissue-engineered repair of the meniscus. The goal of this study was to examine the hypothesis that IL-1 and TNF- $\alpha$ suppress, while TGF- $\beta 1$ enhances, cellular proliferation and migration in cell and tissue models of meniscal repair.
\end{abstract}

Methods: A micro-wound assay was used to assess meniscal cell migration and proliferation in response to the following treatments for 0 , 24, or 48 hours: 0 to $10 \mathrm{ng} / \mathrm{mL} \mathrm{IL}-1$, TNF- $\alpha$, or TGF- $\beta 1$, in the presence or absence of $10 \%$ serum. Proliferated and total cells were fluorescently labeled and imaged using confocal laser scanning microscopy and the number of proliferated, migrated, and total cells was determined in the micro-wound and edges of each image. Meniscal cell proliferation was also assessed throughout meniscal repair model explants treated with 0 or $10 \mathrm{ng} / \mathrm{mL} \mathrm{IL}-1$, TNF- $\alpha$, or TGF- $\beta 1$ for 14 days. At the end of the culture period, biomechanical testing and histological analyses were also performed. Statistical differences were assessed using an ANOVA and Newman-Keuls post hoc test.

Results: IL-1 and TNF- $\alpha$ decreased cell proliferation in both cell and tissue models of meniscal repair. In the presence of serum, TGF- $\beta 1$ increased outer zone cell proliferation in the micro-wound and in the cross section of meniscal repair model explants. Both IL-1 and TNF- $\alpha$ decreased the integrative shear strength of repair and extracellular matrix deposition in the meniscal repair model system, while TGF- $\beta 1$ had no effect on either measure.

Conclusions: Meniscal cell proliferation in vivo may be diminished following joint injury due to the up-regulation of inflammatory cytokines, thereby limiting native cellular repair of meniscal lesions. Therefore, therapies that can promote meniscal cell proliferation have promise to enhance meniscal repair and improve tissue engineering strategies.

\footnotetext{
* Correspondence: guilak@duke.edu

'Department of Orthopaedic Surgery, Duke University Medical Center, DUMC

Box 3093, Durham, NC 27710, USA

Full list of author information is available at the end of the article
} 


\section{Introduction}

The menisci are C-shaped fibrocartilaginous tissues located between the femoral condyles and tibial plateau in the knee. They provide load bearing capabilities, lubrication, proprioception, joint congruity and joint stability for normal biomechanical function of the knee joint [1-4]. Damage to and loss of function of the menisci through sports-related [5] or degenerative tears are associated with pain and degradative changes in the knee joint that ultimately lead to osteoarthritis (OA) [6-11]. Approximately two-thirds of patients with meniscal tears develop radiographic knee OA within 5 to 15 years of injury [12]. Partial excisions and total meniscectomies for the treatment of meniscal tears are strongly associated with articular cartilage loss and the progression of OA [6-11]. Therefore, current orthopaedic practice aims to preserve meniscal integrity and restore function.

The success of clinical repairs depends on a number of factors including age, time to surgery, and the type and location of the meniscal tear. In general, repairs involving the outer one-third of the meniscus, the vascularized "red-red zone", have the highest likelihood of success [13]. Repairs are less favorable in the inner twothirds of the meniscus, the avascular "white-white zone" $[13,14]$. However, in vitro studies of integrative repair suggest that the intrinsic repair capabilities of the outer and inner zones are similar, supporting the hypothesis that the in vivo presence of vasculature aids in the repair of the outer zone [15]. Nonetheless, differences in extracellular matrix and cell composition between the inner and outer zones may also influence repair. The outer zone contains fibroblast-like cells $[16,17]$ that produce predominantly type I collagen [18-20]. The inner zone consists of fibrochondrocyte-like cells [16,17], both type I and II collagen [18,20], and increased aggrecan content relative to the outer zone [14]. Meniscal plugs from the outer zone inserted into inner zone tissue demonstrate enhanced healing, suggesting that repair capability is related to the intrinsic healing potential of the outer region, rather than the vasculature alone [21].

The integrative repair of meniscal lesions is associated with increased cell accumulation in the repair site [22-27]. However, the respective roles of cell proliferation and migration in integrative repair, and the influence of soluble mediators on these processes are not fully understood. An in vivo canine model consisting of a fibrin clot surgically inserted into an avascular meniscal defect showed that the clot functioned as a scaffold for cell migration and a chemotactic stimulus for cell proliferation [28]. Furthermore, cells can migrate into an acellular meniscal plug in vivo and remodel the tissue [29]. An important factor that may strongly influence meniscal repair is the inflammatory environment within the joint. The inflammatory cytokines interleukin-1 (IL1 ) and tumor necrosis factor-alpha (TNF- $\alpha$ ) are upregulated in injured and OA knee joints [30-33]. In addition, IL- 1 and TNF- $\alpha$ decrease integrative meniscal repair in vitro by increasing matrix metalloproteinase (MMP) activity, sulfated glycosaminoglycan (S-GAG) release, and nitric oxide $(\mathrm{NO})$ production, while simultaneously decreasing cell accumulation and tissue formation at the meniscal repair interface, and ultimately compromising the shear strength of repair $[23-27,34]$. Initial acute exposure to IL-1 for 1 to 3 days potently suppresses meniscal repair for at least 28 days [27], suggesting that the initial inflammatory environment in a joint post-injury may have long-term degenerative effects. In addition, IL- 1 and TNF- $\alpha$ activate other degradative and pro-inflammatory pathways in the meniscus and other joint tissues [30,31,35-37].

While many of the potentially negative effects of IL-1 and TNF- $\alpha$ on meniscal repair have been established at the molecular and tissue levels, the specific effects of these proinflammatory cytokines on meniscal cell migration and proliferation are currently unclear, and several in vitro studies have reported conflicting results. In one study, different concentrations of IL-1 caused increased cell migration as compared to controls in bovine meniscal cells isolated from the outer and middle meniscal zones [38]. Conversely, studies with porcine meniscal repair model tissue explants treated with either IL-1 or TNF- $\alpha$ show decreased cell accumulation in the repair interface without a decrease in cell viability, potentially due to a reduction in cell proliferation and/or migration at the repair site [23,25-27].

Anabolic growth factors have been studied as therapeutics to enhance healing of meniscal injuries. The anabolic growth factor transforming growth factor- $\beta 1$ (TGF- $\beta 1$ ) has been shown to increase meniscal cell proliferation in several in vitro models, including monolayer, explant culture, and meniscal cells seeded on poly-L-lactide (PLLA) scaffolds and three-dimensional collagen sponges [39-43]. In vitro meniscal repair model explants treated with TGF- $\beta 1$ showed increased cell accumulation in the repair interface and increased integrative repair $[24,44]$. In the presence of IL- 1 , TGF- $\beta 1$ increased the interfacial shear strength of repair compared to IL-1 alone, overcoming some of the potent catabolic effects of IL-1 [24]. Bovine meniscal cells transduced with vectors expressing TGF- $\beta 1$ and seeded into the avascular inner zone of the meniscus showed increased cellularity and proteoglycan and collagen synthesis [45]. Furthermore, meniscal cells treated with either 10 or $100 \mathrm{ng} / \mathrm{mL}$ TGF- $\beta 1$ showed marked changes in cell morphology, resulting in a phenotype more similar to fibroblast-like cells [39]. 
The goal of this study was to investigate the effects of the inflammatory cytokines IL-1 and TNF- $\alpha$, and the growth factor TGF- $\beta 1$ on proliferation and migration during cell-mediated repair of the meniscus. We hypothesized that IL-1 and TNF- $\alpha$ suppress cellular proliferation and migration of both inner and outer zone meniscal cells, while TGF- $\beta 1$ enhances cell proliferation and migration of both inner and outer zone cells, in cell and tissue models of meniscal repair. We assessed cell migration and proliferation using a microwound assay with isolated inner and outer zone meniscal cells treated with IL-1, TNF- $\alpha$ or TGF- $\beta 1$. Cells were fluorescently labeled to identify newly proliferated and total cells and were imaged over time to assess the contribution of proliferated and migrated cells to wound healing. Additionally, cell proliferation was assessed in inner and outer zone meniscal repair model explants $[15,23,25-27,34]$ treated with IL- 1 , TNF- $\alpha$ or TGF- $\beta 1$ for 14 days. Meniscus healing was investigated by mechanical testing of the repair model explants to determine the interfacial shear strength and histology was performed to visualize tissue repair and cell viability.

\section{Materials and methods}

\section{Meniscal cell isolation}

Medial menisci were aseptically isolated from the knee joints of skeletally mature, two- to three-year-old female pigs obtained from a local abattoir. The menisci were trimmed to remove all ligamentous and synovial tissue and separated into the inner two-thirds and outer onethird zones [14]. Meniscal cells from the inner and outer zones were enzymatically isolated from the tissue by sequential digestion with $1,320 \mathrm{PUK} / \mathrm{mL}$ pronase (Calbiochem, San Diego, CA, USA) followed by $0.4 \%$ collagenase type I (Worthington, Lakewood, NJ, USA) for three hours, as previously described [46]. After enzymatic isolation, the cells were filtered through a $70 \mu \mathrm{m}$ filter (BD Biosciences, Bedford, MA, USA) and washed three times in Dulbecco's Modified Eagle's Medium high glucose (DMEM with $4.5 \mathrm{~g} / \mathrm{L} \mathrm{D}$-glucose; Invitrogen,
Carlsbad, CA, USA) containing 1,000 units/mL penicillin/streptomycin and $2.5 \mu \mathrm{g} / \mathrm{mL}$ amphotericin B (Invitrogen). Cells were resuspended at a concentration of $1 \times 10^{6}$ cells $/ \mathrm{mL}$ in culture media composed of DMEM, $10 \%$ heat inactivated fetal bovine serum (FBS; HyClone, Logan, UT, USA), $0.1 \mathrm{mM}$ non-essential amino acids (Invitrogen), $10 \mathrm{mM}$ 4-(2-hydroxyethyl)-1-piperazineethanesulfonic acid buffer solution (HEPES; Invitrogen), 100 units/mL penicillin/streptomycin, and $37.5 \mu \mathrm{g} /$ $\mathrm{mL}$ L-ascorbic acid 2-phosphate (Sigma-Aldrich, St. Louis, MO, USA). Cells were seeded at a final concentration of $2 \times 10^{6}$ cells per well in a two-well chambered coverglass slide (Nalge Nunc International, Rochester, NY, USA) that was coated overnight with $50 \mu \mathrm{g} / \mathrm{mL}$ bovine type I collagen (Trevigen, Gaithersburg, MD, USA) in phosphate buffered saline (PBS; Mediatech, Manassas, VA, USA). Cells were incubated for 72 hours at $37^{\circ} \mathrm{C} / 5 \% \mathrm{CO}_{2}$.

\section{Micro-wounding of meniscal cells}

We utilized a micro-wound assay, or scratch test, as described previously [47-49] to assess meniscal cell migration and proliferation in monolayer culture $(\mathrm{n}=$ three or more wells per treatment group, each from a different animal). Cells were serum-starved for one hour in serum free culture media (no FBS but contained 2 $\mathrm{mg} / \mathrm{mL}$ bovine serum albumin (BSA; Invitrogen) [38]). After serum starvation, a single vertical scratch was made in the center of each well with a $200 \mu \mathrm{L}$ yellow plastic pipette tip (USA Scientific, Ocala, FL, USA) to remove all cells and generate a micro-wound. Immediately, cell debris and media were aspirated and fresh serum free culture media was added containing $10 \mu \mathrm{M}$ 5-ethylnyl-2'-deoxyuridine (EdU from the Click-iTтM EdU Alexa Fluor ${ }^{\circledR} 488$ Imaging Kit; Invitrogen), to label DNA in proliferating cells, and the treatments listed in Table 1. Cells were incubated at $37^{\circ} \mathrm{C} / 5 \% \mathrm{CO}_{2}$ for 0,24 , or 48 hours then fixed with $3.8 \%$ formaldehyde (VWR International, West Chester, PA, USA), and permeabilized with $0.5 \%$ Triton X-100 (Sigma-Aldrich). EdU detection was performed using the manufacturer's

Table 1 Treatments for micro-wounding experiments

\begin{tabular}{|c|c|c|}
\hline Treatments & Concentrations & Vendor \\
\hline Serum & $0,1 \%, 5 \%, 10 \%$ & Hyclone (Logan, UT, USA) \\
\hline Recombinant porcine IL-1 $\alpha$ & $0,0.1 \mathrm{ng} / \mathrm{mL}, 1 \mathrm{ng} / \mathrm{mL}, 10 \mathrm{ng} / \mathrm{mL}$ & R \& D Systems (Minneapolis, MN, USA) \\
\hline Recombinant porcine TNF- $\alpha$ & 0, $0.1 \mathrm{ng} / \mathrm{mL}, 1 \mathrm{ng} / \mathrm{mL}, 10 \mathrm{ng} / \mathrm{mL}$ & R \& D Systems (Minneapolis, MN, USA) \\
\hline Porcine TGF- $\beta 1$ & 0, $0.1 \mathrm{ng} / \mathrm{mL}, 1 \mathrm{ng} / \mathrm{mL}, 10 \mathrm{ng} / \mathrm{mL}$ & R \& D Systems(Minneapolis, MN, USA) \\
\hline \multirow[t]{4}{*}{$10 \%$ Serum and factors } & $10 \%$ Serum & Hyclone (Logan, UT, USA) \\
\hline & $10 \%$ Serum +10 ng/mL IL-1 & see above \\
\hline & $10 \%$ Serum +10 ng/mL TNF- $\alpha$ & see above \\
\hline & $10 \%$ Serum +10 ng/mL TGF- $\beta 1$ & see above \\
\hline
\end{tabular}

Hyclone (Logan, UT, USA); R \& D Systems (Minneapolis, MN, USA) 
protocol for the Click-iT EdU Alexa Fluor 488 Imaging Kit to label proliferated cells. Cells were washed in tris ethylenediaminetetraacetic acid (TE), $\mathrm{pH} 7.4$, stained for 30 minutes in the dark with $1 \mu \mathrm{M}$ Syto ${ }^{\circledR} 82$ nucleic acid stain (Invitrogen) to label all cells, and washed three times with TE.

Cells were visualized and photographed using a laser scanning confocal microscope (LSM 510, Carl Zeiss, Inc., Thornwood, NY, USA). To visualize proliferated cells, an excitation wavelength of $488 \mathrm{~nm}$ was used and fluorescence was collected at 505 to $530 \mathrm{~nm}$. Total cells were detected by excitation at $543 \mathrm{~nm}$ and fluorescence was collected at $>585 \mathrm{~nm}$. In order to visualize a single cell layer, an optical slice of $15 \mu \mathrm{m}$ was utilized. For each sample, the micro-wound was centered in the field of view and four images at different vertical positions along the scratch were obtained.

\section{Micro-wounding image analysis}

The confocal images were exported as separate green and red channel images from the Zeiss LSM Image Browser software (Carl Zeiss, Inc.). Collected images were analyzed using a custom Matlab (MathWorks, Natick, MA, USA) script. Briefly, each of the four green and red channel images for each sample was thresholded using optimal threshold values that were determined for the green and red channels individually. These images were then converted to a binary image to identify labeled cells. Images were subdivided into 32 32-pixel regions and the number of cells within each region was counted. Cell counts from all regions were summed across the four images to yield the total number of cells (red) and the total number of proliferating cells (green) for each sample. The total number of migrating cells that did not proliferate was the difference between the two channels. To assess cell migration and proliferation in the micro-wound, cell counts were averaged across the two center strips and to assess cell proliferation at the edge, cell counts from the green channel images were averaged across the four peripheral strips at the far left and right edges of the image. The total cell counts at the edges were also measured on Day 0 images to establish the starting cell density for each meniscal cell population. All data are expressed as a percentage of the starting cell density.

In the micro-wounding assay, all cells that accumulate in the gap have migrated into the wound from the edge. Therefore, all cells that are described as proliferated in the gap have in fact both migrated and proliferated. However, the order in which these cellular activities occurred could not be assessed. Cells that are described as migrated have, therefore, only migrated into the wound and did not proliferate.

\section{Meniscal repair model system}

A previously described meniscal repair model system [15,23-27] was used to assess in vitro integrative meniscal repair $(\mathrm{n}=$ four or more per treatment group, all from different animals). Cylindrical $5 \mathrm{~mm}$ biopsy punches (Miltex, York, PA, USA) were harvested perpendicular to the femoral surface of the meniscus from the inner two-thirds and outer one-third of the tissue. Explants were cut parallel to the meniscal surface with a scalpel to a uniform thickness of $2.5 \mathrm{~mm}$ using a custom-made cutting block. To simulate a full-thickness tear, a $3 \mathrm{~mm}$ biopsy punch (Miltex) was utilized to make a concentric core in the explant, which was removed and immediately reinserted in the original orientation. Explants were placed in a 24-well plate with DMEM containing 1,000 units/mL penicillin/streptomycin for one hour at $37^{\circ} \mathrm{C} / 5 \% \mathrm{CO}_{2}$. Explants were incubated in the culture media described above for isolated meniscal cells. For cell proliferation experiments, all media included $10 \mu \mathrm{M}$ EdU. Explants were randomly assigned to one the following treatment groups: control, $10 \mathrm{ng} / \mathrm{mL}$ IL- $1 \alpha, 10 \mathrm{ng} / \mathrm{mL}$ TNF- $\alpha$ or $10 \mathrm{ng} / \mathrm{mL}$ TGF$\beta 1$. Media were changed every 3 days, and explants were cultured for a total of 14 days at $37^{\circ} \mathrm{C} / 5 \% \mathrm{CO}_{2}$.

\section{Cell proliferation analyses in meniscal repair explants}

On Day 14, explants were transected vertically to allow visualization of cells throughout the cross section. Explants were labeled using a modified protocol based on the Click -iT ${ }^{\mathrm{TM}}$ EdU Alexa Fluor ${ }^{\circledR} 488$ Imaging Kit. Briefly, explants were fixed with $3.8 \%$ formaldehyde for 30 minutes, permeabilized with $0.5 \%$ Triton X-100 for 30 minutes, and tagged with the Alexa Fluor dye to label all proliferated cells. To stain all cells, explants were washed in TE, $\mathrm{pH} 7.4$, stained for 30 minutes in the dark with $1 \mu \mathrm{M}$ Syto ${ }^{\circledR} 82$ nucleic acid stain, and then washed three times with TE.

Cells were visualized and photographed using a confocal laser scanning microscope as described above for the micro-wounding assay. Images were collected more than $50 \mu \mathrm{m}$ into the face of the sample to ensure that cells damaged during transection were excluded [50]. Two images per location were collected from the outer ring, inner core and repair interface for both the surface and cross section of the explants.

\section{Meniscal repair model explant image analysis}

Data were collected from different areas of the surface and cross-section of the meniscal repair model explants. Measured areas were outlined in Zeiss LSM image browser (Carl Zeiss). The surface interface included a 50 $\mu \mathrm{m}$ region on either side of the interface, inclusive of the interface, at the surface of the tissue. The surface region of the tissue included images from both the 
inner core and outer ring that were outside this defined interface region. For cross section images, the tissue was divided into three distinct layers based on distance from the surface and cell morphology. The first $50 \mu \mathrm{m}$ from the surface was defined as the "superficial zone," the next $100 \mu \mathrm{m}$ was defined as the "middle zone," and the next $300 \mu \mathrm{m}$ was termed the "deep zone." The cross section interface included a $50 \mu \mathrm{m}$ region on either side of the interface, inclusive of the interface, for each of these three layers. The cross section of the tissue included images of the cross section from both the inner core and outer ring that were outside the defined interface region.

Confocal images were exported as separate green and red channel images and saved as TIFF files. The images were gray-scaled using Adobe Photoshop and processed using Scion Image (Scion Corp., Frederick, MD, USA) to invert, subtract background by removing 2D streaks, and smooth. Optimal threshold values were determined for the green and red channels individually. Proliferated cells (green) and total cell (red) counts were obtained using intensity thresholds of 75 and 40, respectively, and a minimum particle size of five. Cell counts were obtained for each of the defined regions in the surface and cross sectional planes. Percent cell proliferation was calculated by dividing the number of proliferated cells (green) by the number of total cells (red) in each sample and multiplying by 100 percent.

\section{Biomechanical testing to assess shear strength of repair} On Day 14, shear strength of repair between the outer ring and inner core of meniscal repair explants was measured with a push-out test [15,23-27] using an Electroforce (ELF) 3200 materials testing system (BoseEnduraTEC Corporation, Eden Prairie, MN, USA). Briefly, explants were centered in a custom-made apparatus, such that the $3 \mathrm{~mm}$ inner core was centered over a $4 \mathrm{~mm}$ concentric hole in the bottom of the dish. A 2 $\mathrm{mm}$ diameter rod attached to a load cell displaced the inner core at a rate of $0.0833 \mathrm{~mm} / \mathrm{s}$ until the inner core was dislodged from the outer ring. The force required for displacement was recorded over time. Following the push out test, the inner core was imaged using a digital video camera (Sony Electronics, Park Ridge, NJ, USA) with a 94-mm video lens (Infinity, Boulder, CO, USA) to measure the inner core thickness using LabVIEW Vision Builder AI (National Instruments Corporation, Austin, TX, USA). Shear strength of repair (in $\mathrm{kPa}$ ) was calculated by dividing the peak force measured during the push out test by the surface area of the interface.

\section{Histological staining of meniscal explants}

On Day 12 of the meniscal repair model explant culture, $0.05 \%$ nitroblue tetrazolium chloride (NBT;
Invitrogen) was added to the explant culture media for histological analyses. NBT is a cell-permeable compound that is reduced by live cells to form a blue formazan product that remains stable to histological processing and paraffin embedding and has been documented as a live cell marker for chondrocytes [51,52]. At Day 14, explants were fixed overnight in 4\% paraformaldehyde (Electron Microscopy Sciences, Hatfield, PA, USA), containing $100 \mathrm{mM}$ sodium cacodylate trihydrate (Electron Microscopy Sciences), pH 7.4 at $4{ }^{\circ} \mathrm{C}$. Samples were dehydrated in $\mathrm{EtOH}$, infiltrated with xylene, and paraffin embedded. Sections were stained with $0.02 \%$ aqueous fast green (Sigma-Aldrich) to label collagens and Accustain Safranin O solution (Sigma-Aldrich) to identify proteoglycans.

\section{Statistical analyses}

Statistical analyses were performed using Statistica 7.0 (StatSoft Inc., Tulsa, OK, USA). A factorial analysis of variance (ANOVA) and the Newman-Keuls post hoc test were performed to determine significant differences $(\alpha=$ 0.05 ) and the interactive effect of time and treatment in the micro-wounding experiments. In the meniscal repair model explant studies, the interactive effect of treatment and tissue zone (inner and outer) in the surface images and push-out test and of treatment, tissue zone and cross section layer (superficial, middle, and deep) in the cross section images were also determined using a factorial ANOVA and Newman-Keuls post-hoc test.

\section{Results \\ The effects of serum on inner and outer zone micro- wound repair}

Serum treatment of meniscal cells from both the inner (Figure 1A) and outer zones (Figure 1C) resulted in increased accumulation of proliferated cells in the micro-wound. For inner zone meniscal cells, $10 \%$ serum increased the total number of cells in the wound as compared to the control (Figure 1B, $\mathrm{P}<0.05$ ), increased the percentage of proliferated cells in the wound compared to all other treatments $(P<0.005)$, and enhanced cellular proliferation away from the wound over the control and $1 \%$ serum treatments $(P<0.05)$. Additionally, $5 \%$ serum promoted cellular proliferation in the wound over the control treatment $(P<0.05)$. There was also an effect of time in the inner zone cells, with increased proliferation at both the edge and in the wound at 48 hours $(P<0.005)$, while the number of cells that had migrated but not proliferated in the wound decreased from 24 to 48 hours $(P<0.05)$.

In outer zone meniscal cells, $10 \%$ serum increased the total number of cells in the wound (Figure 1D, P < $0.005)$ and the percentage of proliferated cells in both the wound $(P<0.01)$ and at the edge $(P<0.005)$, as 


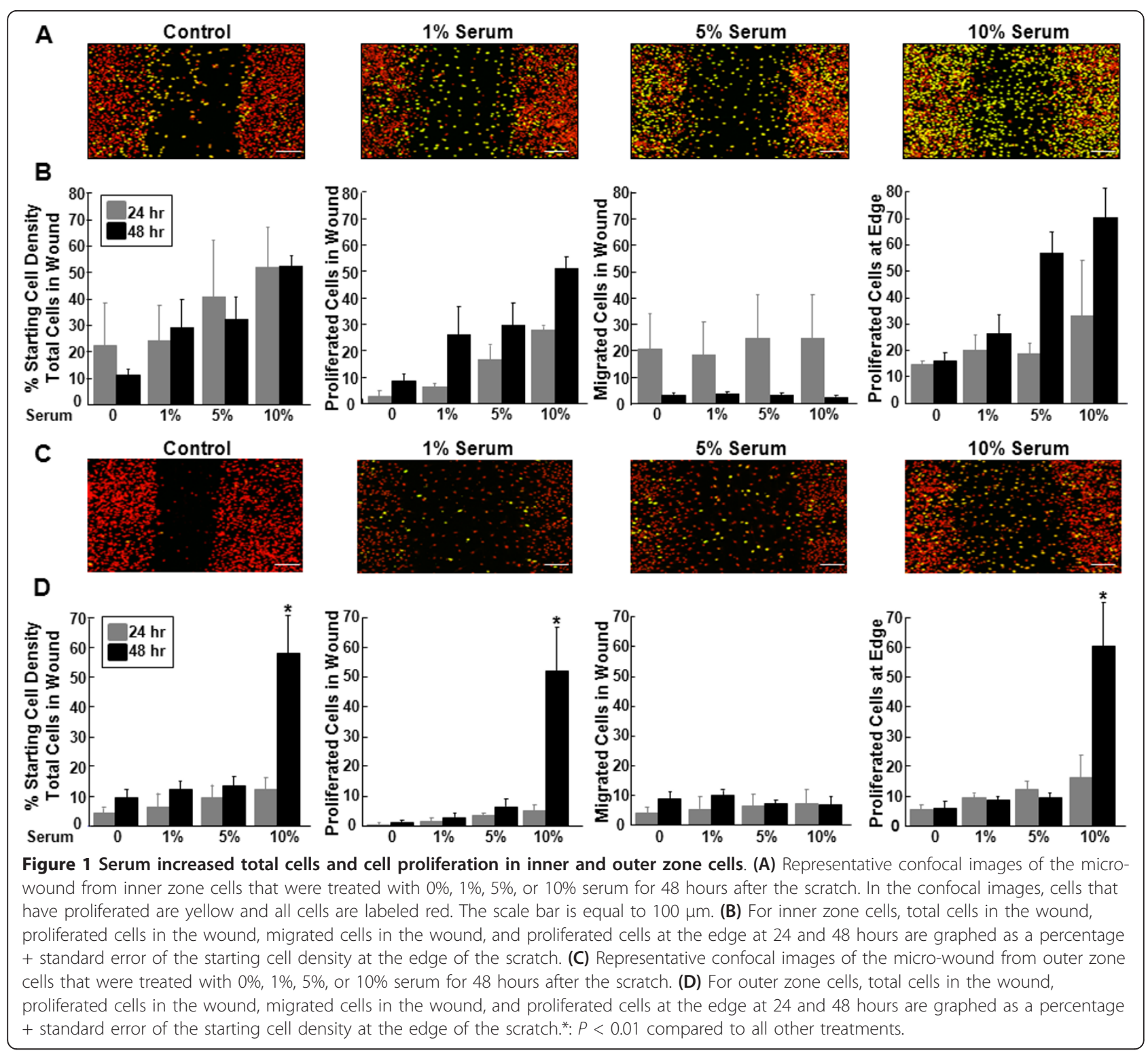

compared to all other treatments. On average, treatment with $10 \%$ serum for 48 hours resulted in a six-fold increase in the total number of cells in the wound and in the proliferated cells at both the edge and in the wound $(P<0.01)$. In addition, there was an effect of time in the outer zone cells, with the total number of cells $(P<0.005)$ and the proliferated cells in the wound being greatest at 48 hours $(P<0.01)$. No differences were detected in cells that migrated but did not proliferate in the wound of outer zone cells.

The effects of IL-1 on inner and outer zone micro-wound repair

IL-1 treatment of meniscal cells from the inner (Figure $2 \mathrm{~A}$ ) or outer zones (Figure $2 \mathrm{C}$ ) resulted in decreased accumulation of proliferated cells in the micro-wound. As compared to the inner zone control at 48 hours, the overall total number of cells in the wound and the proliferated cells in the wound were significantly decreased by IL- 1 treatment (Figure $2 \mathrm{~B}, \mathrm{P}<0.01$ ). However, 0.1 $\mathrm{ng} / \mathrm{mL}$ IL-1 at 48 hours showed an increase in the total cells in the wound, as compared to all other treatments at 24 hours $(P<0.05)$, and a corresponding increase in the number of cells that migrated but did not proliferate in the wound, as compared to all other treatments at both 24 and 48 hours $(P<0.005)$. There was a significant increase in the number of migrated cells in the wound at 48 hours in the $1 \mathrm{ng} / \mathrm{mL}$ and $10 \mathrm{ng} / \mathrm{mL}$ IL-1 treatment groups $(P<0.05)$. Overall for inner zone cells, the control treatment caused the greatest 


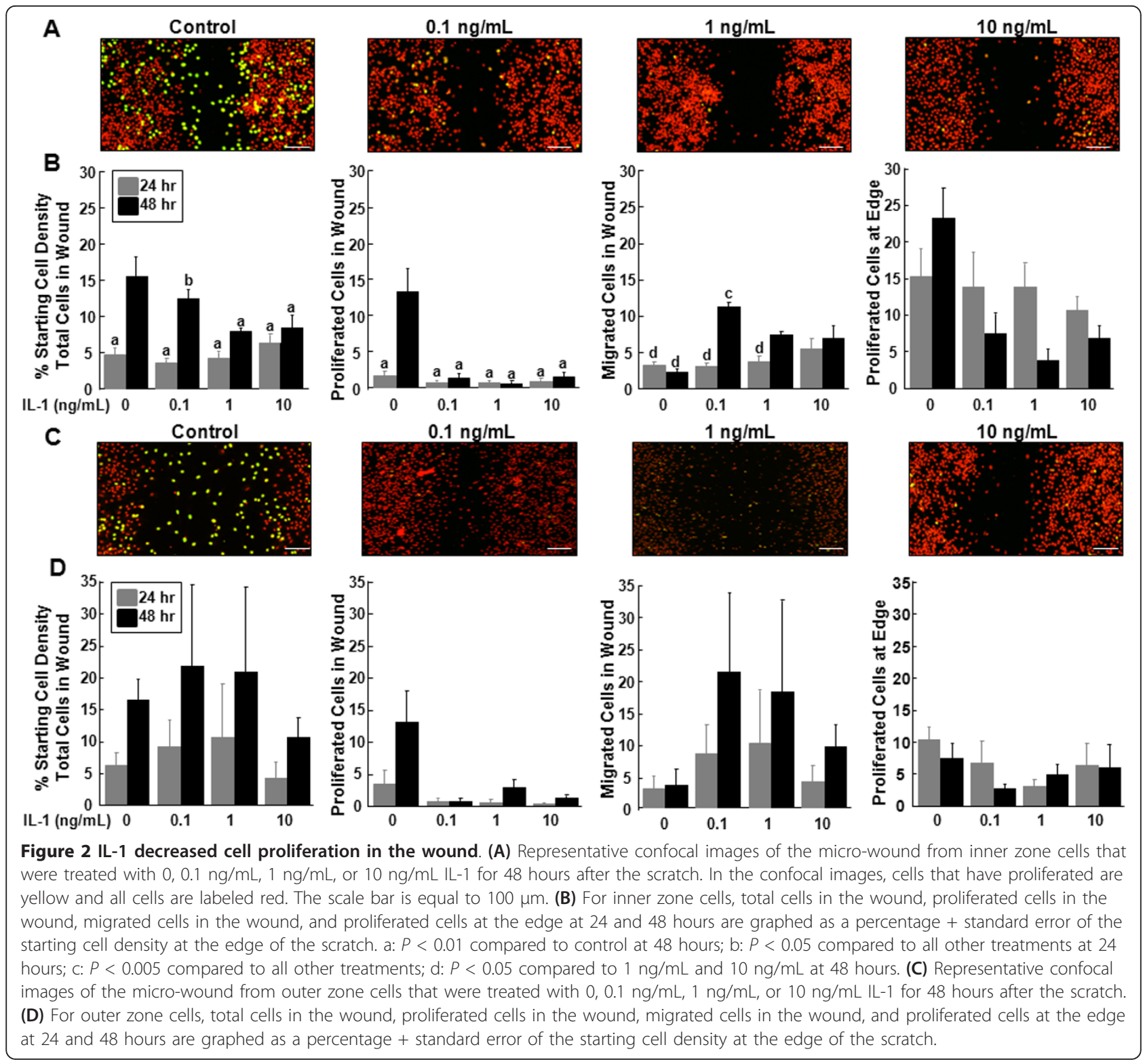

proliferation at the edge $(P<0.05)$ and in the wound $(P$ $<0.0005)$ and decreased the number of cells that migrated but did not proliferate in the wound $(P<$ 0.005). There was also an effect of time, with 48 hours showing increased total cells, proliferated cells and migrated cells in the wound, as compared to the 24hour time point $(P<0.001)$.

In the outer zone meniscal cells, IL-1 treatment caused a significant decrease in the number of proliferated cells in the wound, as compared to control (Figure $2 \mathrm{D}, \mathrm{P}<0.05)$. However, IL-1 did not have a significant effect on the total cell numbers in the wound, migrated cells in the wound, or the proliferated cells at the edge in the outer zone meniscal cells.
The effects of TNF- $\alpha$ on inner and outer zone microwound repair

Meniscal cells from the inner (Figure 3A), but not the outer zone (Figure 3C), showed diminished accumulation of proliferated cells in the micro-wound with increasing concentrations of TNF- $\alpha$. In the inner zone cells, proliferation at the edge was diminished by all concentrations of TNF- $\alpha$ (Figure 3B, P $<0.05$ ), as compared to control. In addition, the 1 and $10 \mathrm{ng} / \mathrm{mL}$ concentrations of TNF- $\alpha$ caused significant decreases in proliferation at the edge, as compared to $0.1 \mathrm{ng} / \mathrm{mL}$ TNF- $\alpha(P<0.005)$. At 48 hours, proliferation in the wound was significantly higher than at 24 hours $(P<$ $0.05)$. In the inner zone cells treated with TNF- $\alpha$, there 


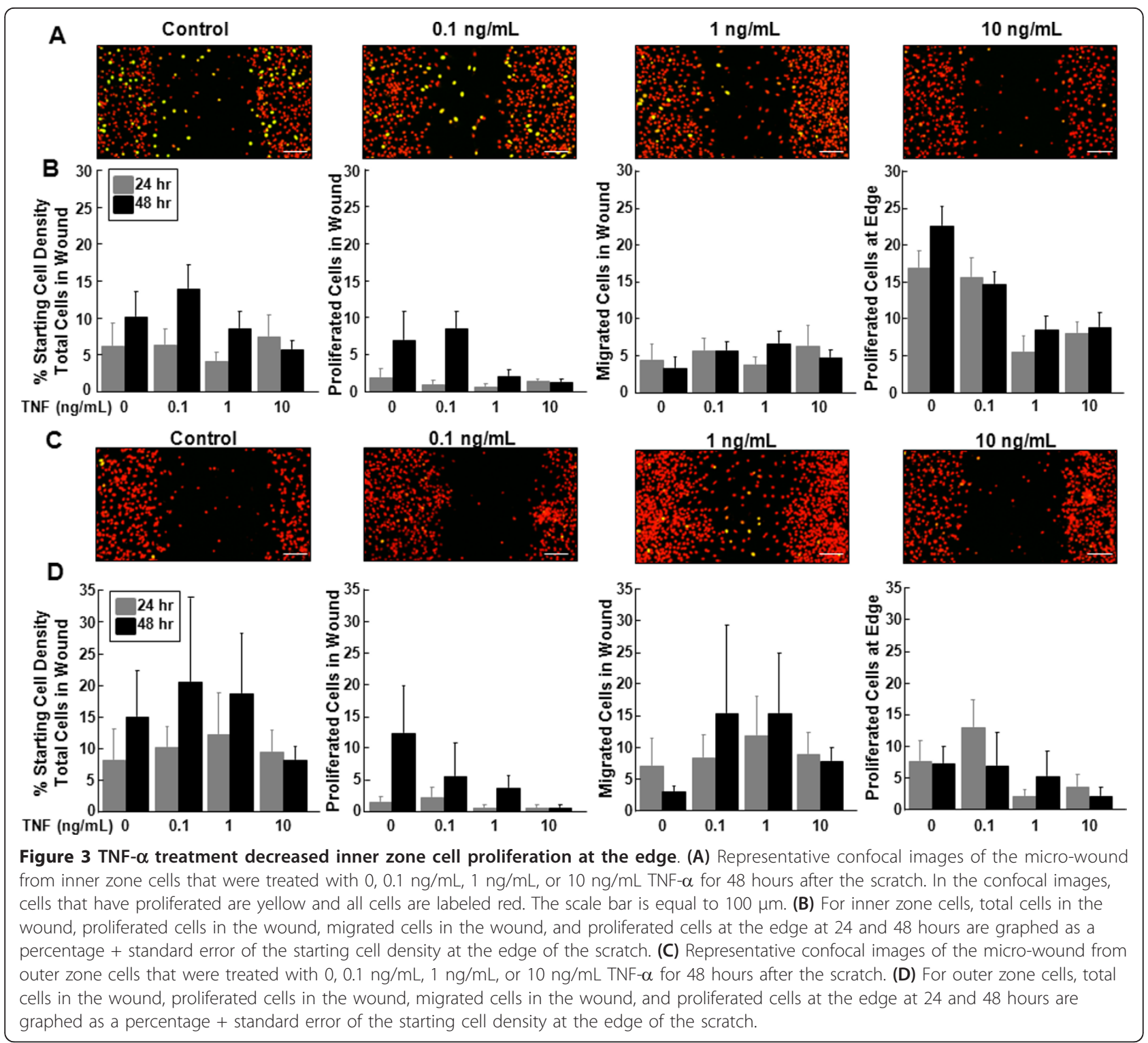

were no differences in the total cells in the wound or migrated cells in the wound.

In the outer zone cells, there was a trend towards decreased proliferation at the edge (Figure $3 \mathrm{D}, \mathrm{P}=0.17$ ) and in the wound $(P=0.46)$ with TNF- $\alpha$ treatment but these changes were not significant. TNF- $\alpha$ treatment did not alter the total number of cells in the wound or the number of cells that had migrated but not proliferated in the wound.

\section{The effects of TGF- $\beta 1$ on inner and outer zone micro- wound repair}

In the inner zone meniscal cells, there were no observable changes in cell accumulation or proliferation (Figure $4 \mathrm{~A}$ ). For the inner zone cells, total cells (Figure 4B,
$\mathrm{P}<0.05)$ and proliferated cells in the wound $(P<$ $0.005)$ increased with time. No changes were observed with TGF- $\beta 1$ treatment in the cells that proliferated at the edge or in cells that migrated but did not proliferate in the wound.

On the other hand, in the outer zone cells $0.1 \mathrm{ng} / \mathrm{mL}$ TGF- $\beta 1$ increased cell accumulation (Figure $4 \mathrm{C}$ ). This concentration of TGF- $\beta 1$ also significantly increased the total cell number in the wound of the outer zone cells, as compared to the control and $1 \mathrm{ng} / \mathrm{mL}$ TGF- $\beta 1$ treatment groups (Figure 4D, $\mathrm{P}<0.05$ ). However, TGF- $\beta 1$ treatment of outer zone cells did not alter the percentage of proliferated cells in the wound, proliferated cells at the edge, or the number of cells that had migrated into the wound but not proliferated. 


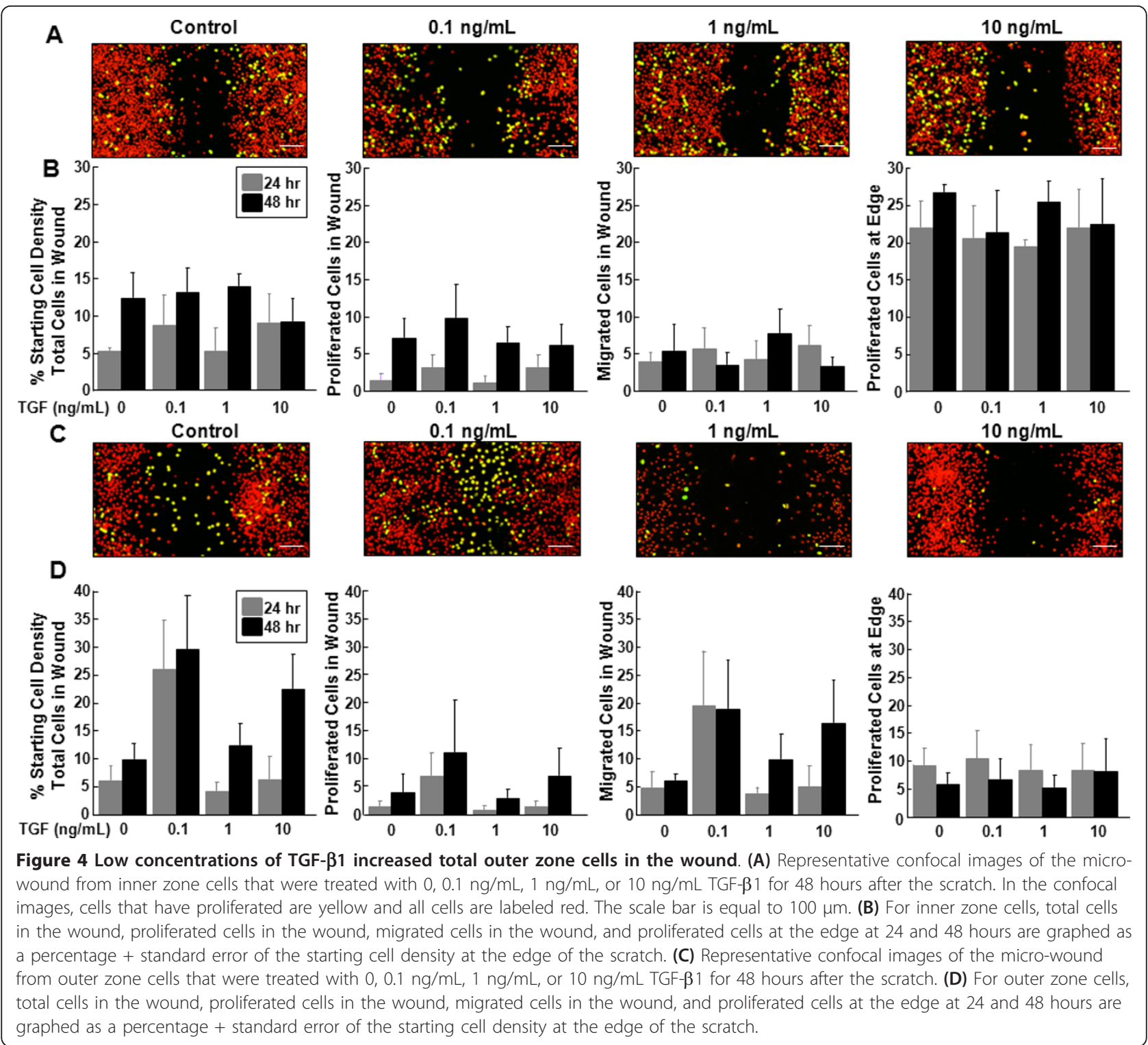

The effects of IL-1, TNF- $\alpha$, and TGF- $\beta 1$ in the presence of serum on inner and outer zone micro-wound repair

In the presence of serum, IL-1 and TNF- $\alpha$ treatment of meniscal cells from both the inner (Figure $5 \mathrm{~A}$ ) and outer zones (Figure $5 \mathrm{C}$ ) resulted in decreased accumulation of proliferated cells in the micro-wound. For inner zone cells, both IL- 1 and TNF- $\alpha$ decreased total cell numbers in the wound and the percentage of proliferated cells in the wound and at the edge, as compared to $10 \%$ serum treatment for 48 hours (Figure $5 \mathrm{~B}, \mathrm{P}<0.05$ ). In addition, IL- 1 and TNF- $\alpha$ suppressed cell proliferation in the wound and at the edge compared to TGF- $\beta 1$ treatment for 48 hours $(P<0.05)$. Even at 24 hours, TNF- $\alpha$ suppressed total cells in the wound relative to TGF- $\beta 1$ treatment $(P<0.05)$. There was an increase in the total number of inner zone cells in the wound and proliferated cells in the wound and at the edge over time $(P<0.05)$. None of the tested factors affected inner zone cell migration into the wound in the presence of serum.

In the outer zone cells, TGF- $\beta 1$ treatment at 48 hours significantly increased cell proliferation in the wound compared to all other treatments (Figure 5D, $\mathrm{P}<0.05$ ). In addition, TGF- $\beta 1$ treatment also promoted cell proliferation at the edge $(P<0.05)$. Furthermore, total cells $(P$ $<0.05)$ and proliferated cells in the wound $(P<0.005)$ increased over time. There was no effect on cell migration into the wound of outer zone cells with the different factors in the presence of serum. 


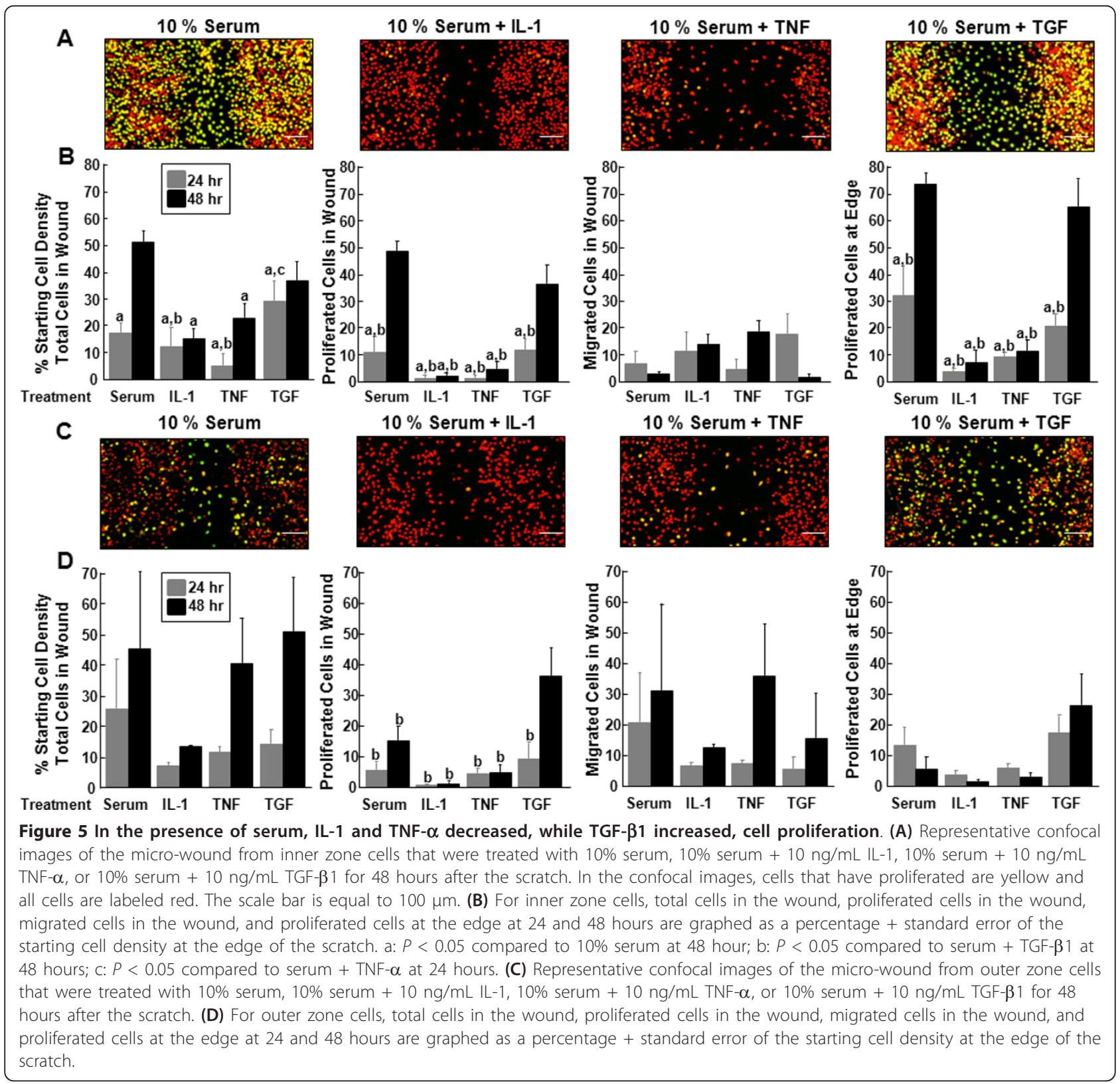

The effects of IL-1 on cellular proliferation in meniscal repair model explants

Cellular proliferation at the meniscal tissue surface (Figure $6 \mathrm{~B}, \mathrm{C}$ ), surface interface (Figure $7 \mathrm{~B}, \mathrm{C}$ ), cross-section (Figure 8B, C), and cross-section interface (Figure 9B, C) were decreased by IL-1 in both inner and outer meniscal repair explants. In both the inner and outer zone explants, IL-1 potently inhibited cell proliferation at the tissue surface (Figure 6D, $\mathrm{P}<0.00005$ ) and the surface interface (Figure 7D, $\mathrm{P}<0.005$ ). In addition, IL-1 decreased cell proliferation throughout the cross-section (Figure $8 \mathrm{D}, \mathrm{P}<0.000005$ ) and cross-section interface
(Figure 9D, $\mathrm{P}<0.0001)$. In the cross-section, there was a significant difference between all layers with the superficial layer having the highest percentage of proliferated cells and the deep layer having the lowest percentage (Figure 8D, $\mathrm{P}<0.05)$. Furthermore, there was an interactive effect of IL- 1 and cross-section layer $(P<0.000005)$. In the cross-section interface, the deep layer had significantly less proliferation than the superficial and middle layers of the tissue (Figure 9D, $\mathrm{P}<0.01$ ). Overall in the cross-section interface, cellular proliferation was higher in the outer zone meniscal repair model explants, as compared to the explants from the inner zone $(P<0.05)$. 


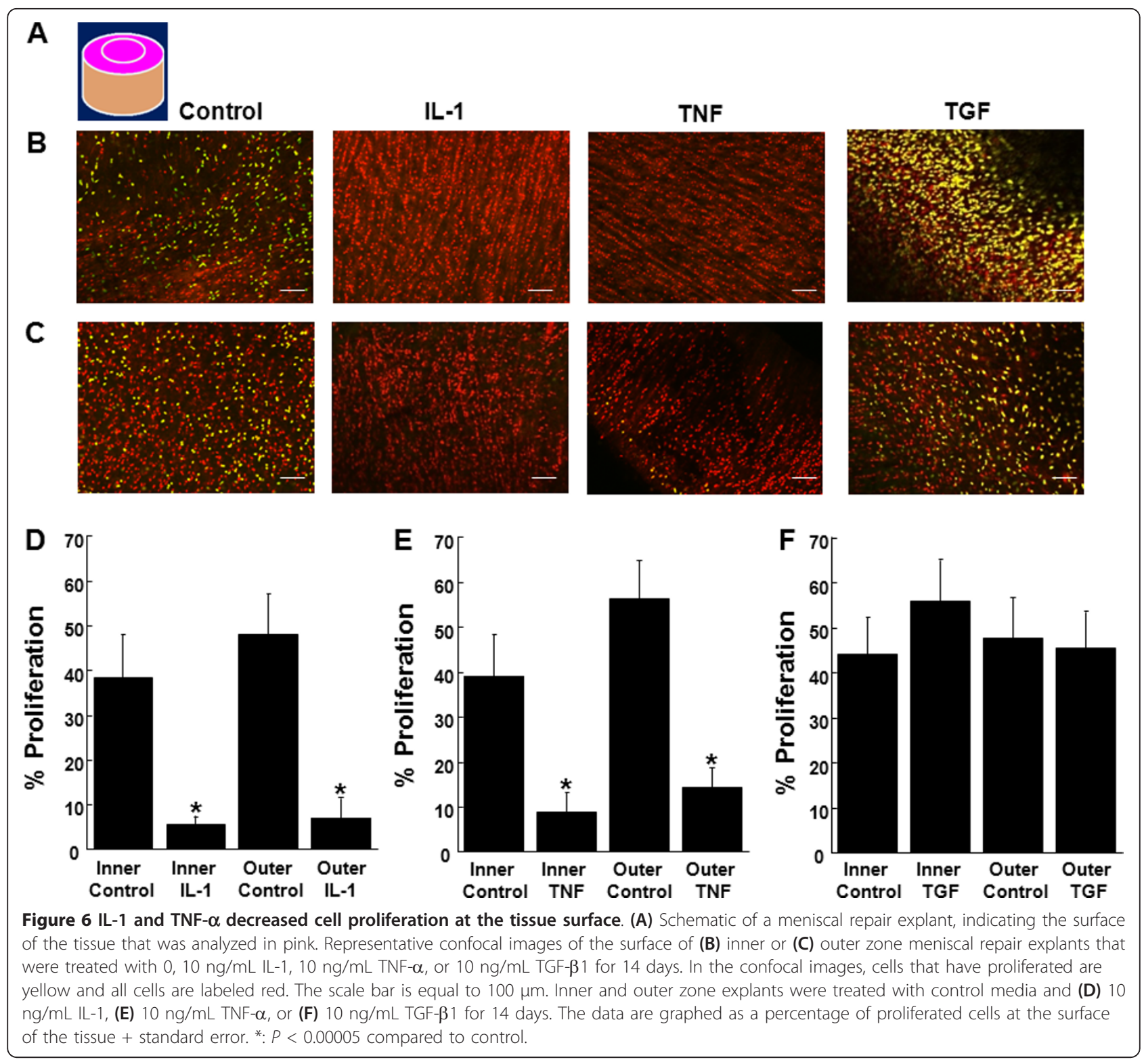

The effects of TNF- $\alpha$ on cellular proliferation in meniscal repair model explants

Cellular proliferation at the meniscal tissue surface (Figure $6 \mathrm{~B}, \mathrm{C}$ ), surface interface (Figure $7 \mathrm{~B}, \mathrm{C}$ ), cross-section (Figure 8B, C), and cross-section interface (Figure 9B, C) were decreased in the presence of TNF- $\alpha$ in both inner and outer meniscal repair explants. TNF- $\alpha$ strongly inhibited cell proliferation at the tissue surface (Figure $6 \mathrm{E}, \mathrm{P}<0.00005$ ) and the surface interface (Figure $7 \mathrm{E}, \mathrm{P}$ $<0.005)$ in explants from both zones. Furthermore, TNF- $\alpha$ reduced cell proliferation throughout the crosssection (Figure $8 \mathrm{E}, \mathrm{P}<0.000005$ ) and cross-section interface (Figure 9E, $\mathrm{P}<0.000005$ ). There was also a significant effect of cross-section layer with the superficial layer containing significantly more proliferated cells than the middle and deep layers (Figure 8E, $\mathrm{P}<0.0005$ ). In addition, there was an interactive effect of TNF- $\alpha$ and cross-section layer $(P<0.00005)$.

The effects of TGF- $\beta 1$ on cellular proliferation in meniscal repair model explants

In both the inner and outer meniscal repair explants, TGF- $\beta 1$ treatment did not appear to alter cellular proliferation at the meniscal tissue surface (Figure 6B, C), surface interface (Figure $7 \mathrm{~B}, \mathrm{C}$ ), cross-section (Figure $8 \mathrm{~B}, \mathrm{C}$ ), or cross-section interface (Figure 9B, C). In both inner and outer zone explants, TGF- $\beta 1$ had no effect on cellular proliferation in meniscal repair model explants at the tissue surface (Figure 6F), the surface interface (Figure 7F), or the cross-section interface (Figure 9F). 


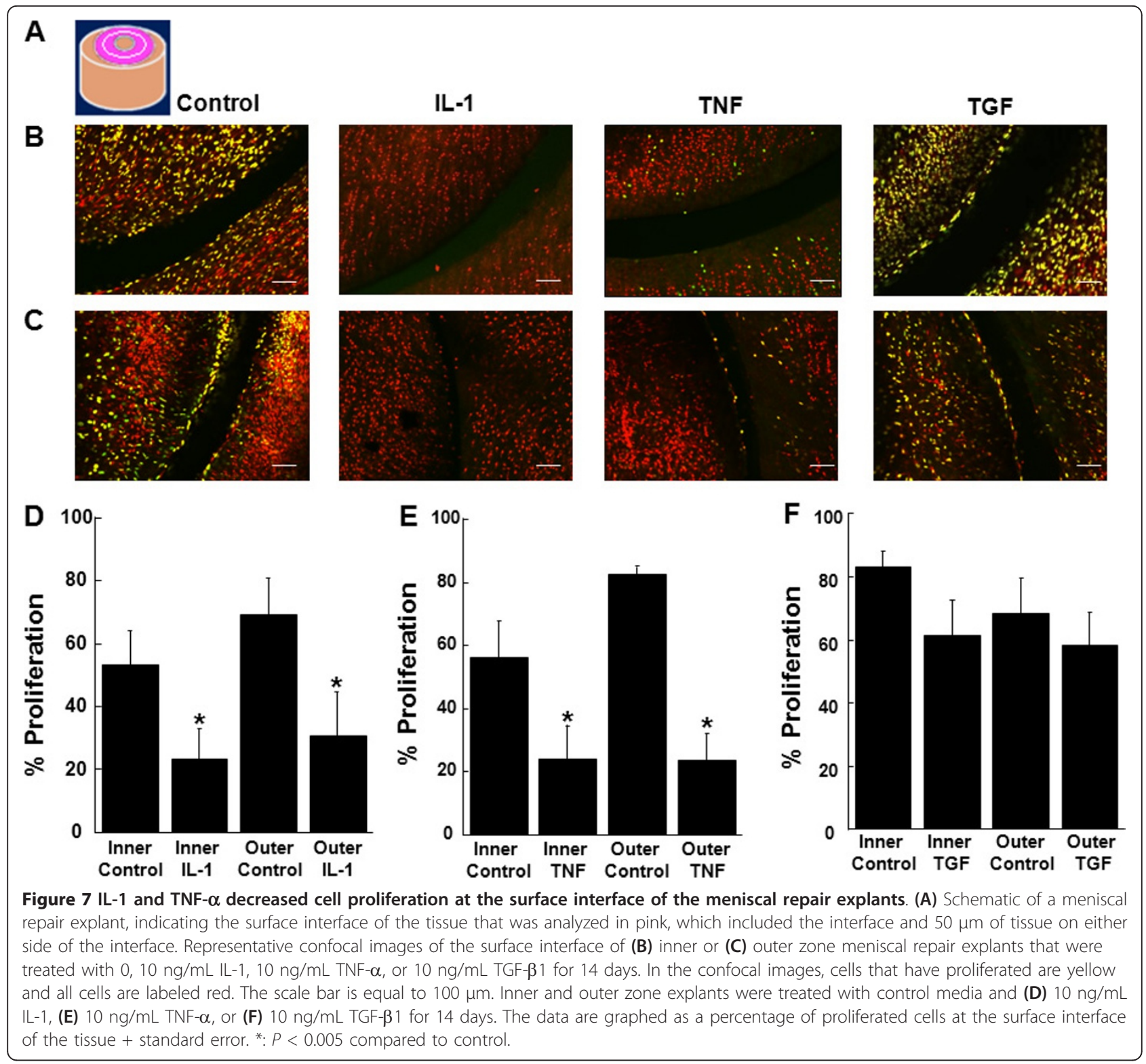

However, overall TGF- $\beta 1$ increased cellular proliferation in the tissue cross-section (Figure $8 \mathrm{~F}, \mathrm{P}<0.05$ ). While there was a significant decrease in cellular proliferation throughout the depth of the meniscus cross-section (Figure 8F, $\mathrm{P}<0.005$ ), TGF- $\beta 1$ most noticeably up-regulated proliferation in the middle and deep layers.

The effects of IL-1, TNF- $\alpha$, and TGF- $\beta 1$ on the shear strength of integrative repair

In the inner and outer zone meniscal explants, both IL-1 (Figure 10A, $\mathrm{P}<0.0005$ ) and TNF- $\alpha$ (Figure 10B, $\mathrm{P}<$ $0.005)$ significantly decreased the integrative shear strength of repair. TGF- $\beta 1$ (Figure 10C) had no effect on the shear strength of the meniscal repair model explants. Outer zone meniscal repair model explants demonstrated increased shear strength of repair, as compared to inner zone explants, when treated with TNF- $\alpha$ (Figure 10B, $\mathrm{P}<0.05$ ) and TGF- $\beta 1$ (Figure 10C, $\mathrm{P}<0.005)$.

The effects of IL-1, TNF- $\alpha$ and TGF- $\beta 1$ on tissue repair and cell viability

Histological analysis revealed healing of the meniscal defect in both inner and outer repair model explants under control conditions (Figures 11A, B). Control inner zone explants stained strongly with safranin $\mathrm{O}$, indicating a relative abundance of proteoglycans, as compared to outer zone samples. In both inner and outer zone explants from the control and TGF- $\beta 1$ treated groups, the repair interface was filled with an extracellular 


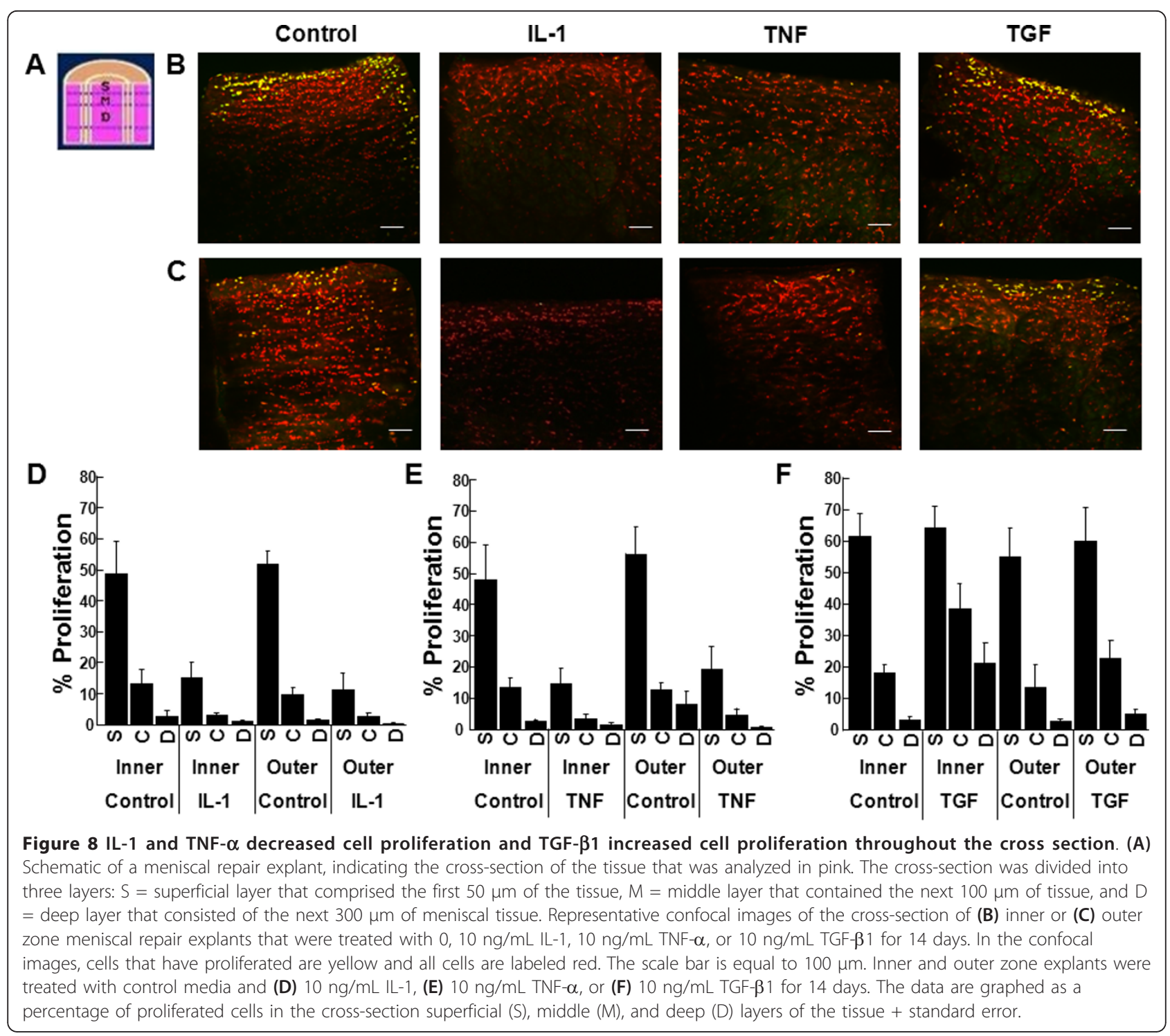

matrix that stained strongly with fast green, indicating the presence of collagen fibers. No visible tissue repair was detected in explants that were treated with either IL-1 or TNF- $\alpha$. Cell viability, as indicated by NBT staining, was not altered in any of the treatment groups.

\section{Discussion}

Our results demonstrate that the proinflammatory cytokines IL-1 and TNF- $\alpha$ decreased cell proliferation in both cell and tissue models of meniscal repair. In the presence of serum, the anabolic growth factor TGF- $\beta 1$ increased outer zone cell proliferation in the microwound and in the cross section of meniscal repair model explants. Furthermore, both IL-1 and TNF- $\alpha$ decreased the integrative shear strength of repair and extracellular matrix deposition in the meniscal repair model system, while TGF- $\beta 1$ had no effect on either measure. Therefore, our results support our hypothesis that the inhibition of cell accumulation and integrative repair by IL- 1 and TNF- $\alpha$ is likely due to suppression of cellular proliferation but not migration of cells into meniscal micro-wounds. These results suggest that in vivo, meniscal cell proliferation may be diminished following joint injury due to the up-regulation of inflammatory cytokines, thereby limiting native cellular repair of meniscal lesions. Therefore, therapies that can promote meniscal cell proliferation have promise to enhance meniscal repair and improve tissue engineering strategies.

Serum has been shown to promote proliferation in many cell types, including chondrocytes [53,54]. Likely growth factors present in the serum promoted healing of the micro-wound [55]. However, inner and outer zone cells exhibited distinct responses in the micro- 


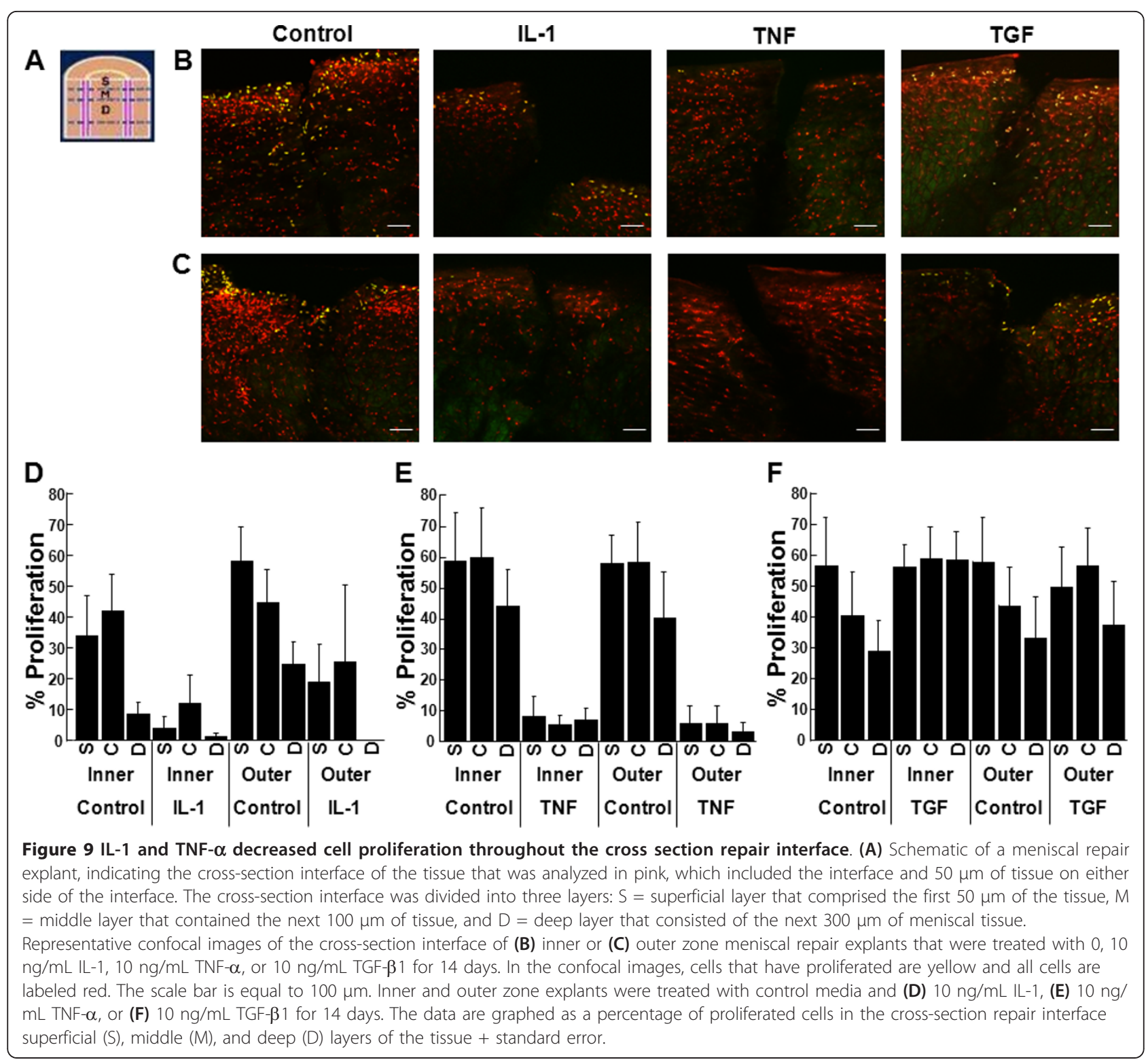

wound assay. The inner zone cells showed increased cell proliferation in response to $5 \%$ and $10 \%$ serum, while outer zone cells were only stimulated by $10 \%$ serum. The inner zone cells may be more sensitive to serum stimulation due to the lack of prior exposure to the contents of the vasculature in the context of the meniscus [14]. In addition, for inner zone cells, the percentage of cells that migrated but did not proliferate decreased over time, suggesting that the cells are migrating into the wound and then proliferating to repair the defect.

IL-1 treatment suppressed cell proliferation but increased migration in inner zone cells at the wound, although the enhanced migration was insufficient to overcome the suppression of proliferation in order to repair the micro-wound. On the other hand, IL-1 treatment of outer zone cells decreased proliferation but did not alter cell migration into the micro-wound. In other studies, outer and middle zone meniscal cells that grew out of bovine menisci over two to three weeks showed increased chemotaxis in response to four hours of 1 to $100 \mathrm{ng} / \mathrm{mL}$ IL-1 [38]. In this study, we did not assess the chemotactic response of the porcine meniscal cells but the differences in our results may be due to the differences in exposure time to IL- 1 . In the presence of serum, IL-1 treatment of inner zone cells suppressed total cell accumulation and proliferation but had no effect on migration. These experimental conditions are most similar to our explant growth conditions, and the results of these experiments are consistent. In porcine articular chondrocytes, F-actin content is increased after 1 hour of $10 \mathrm{ng} / \mathrm{mL}$ IL-1, 

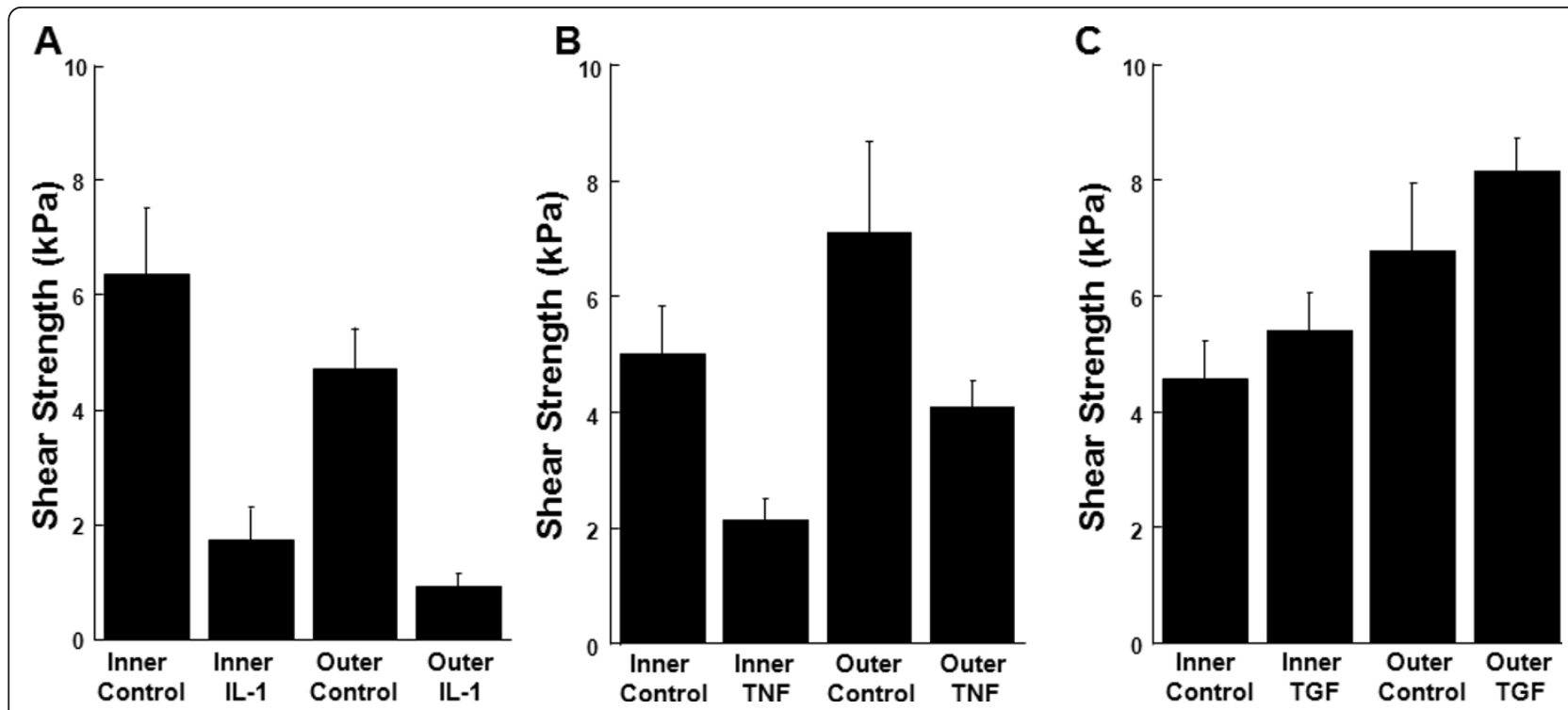

Figure 10 IL-1 and TNF- $\alpha$ decreased the integrative shear strength of repair. Inner and outer zone explants were treated with control

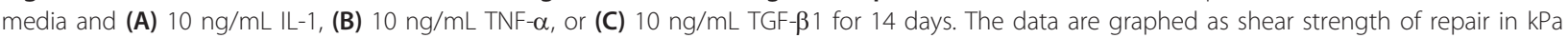
+ standard error.

showing punctate staining at the periphery but this effect is not observed after 12 hours of IL-1 treatment [56]. In tenocytes treated with 100 pM IL-1 $\beta$ for five days, proliferation rate was unchanged; however, actin filaments were disrupted while microtubule structure was unchanged [57]. In addition, chondrocytes treated with exogenous NO, a downstream mediator of IL-1 signaling, showed inhibition of chondrocyte migration and disruption of actin filament assembly [54]. Therefore, disruption of the actin cytoskeleton may be contributing to the IL-1 mediated suppression of proliferation observed in our injury models.

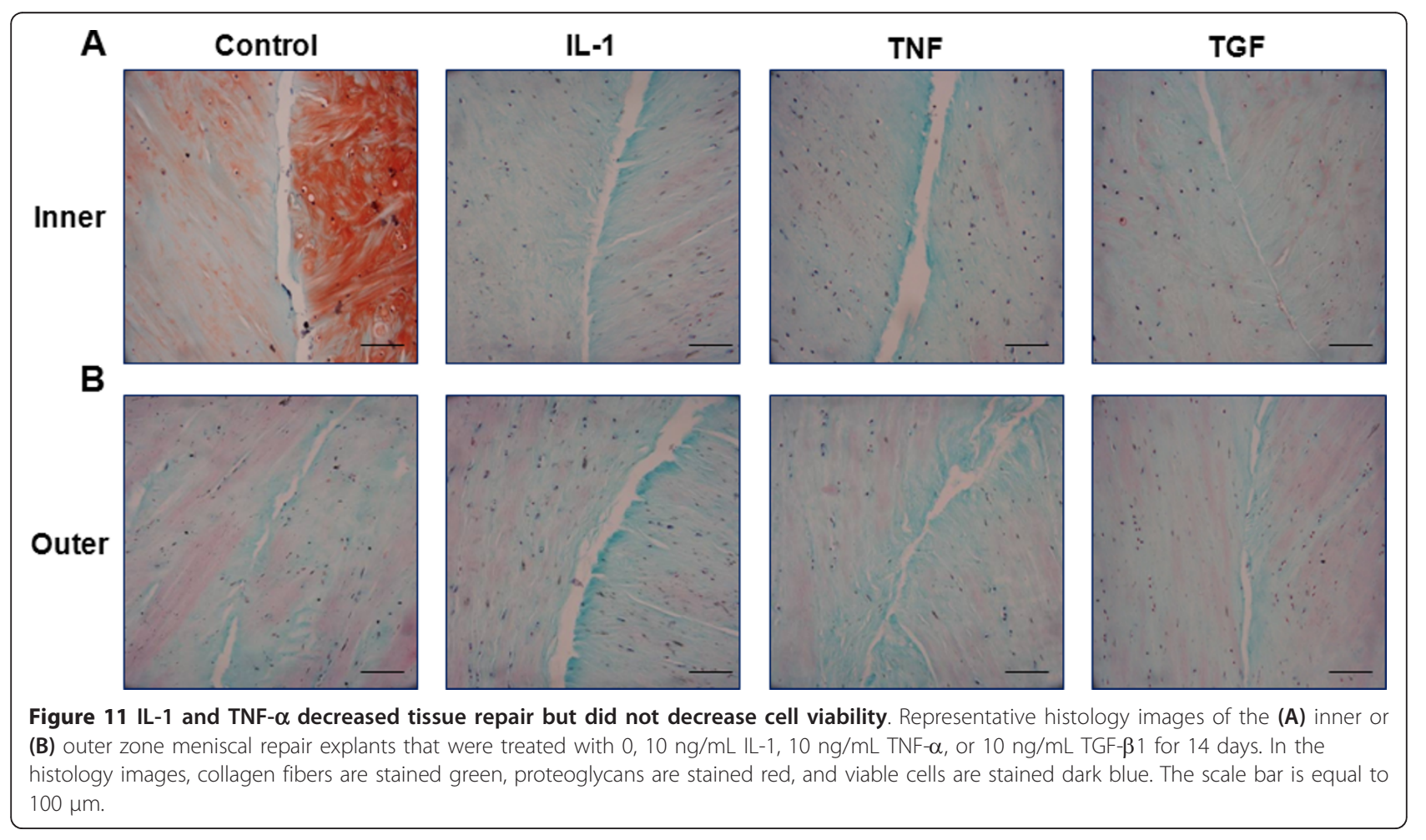


The effect of TNF- $\alpha$ in suppression of proliferation was not as robust as that observed with IL-1, consistent with our previous observations of the different potencies of equal concentrations of IL-1 and TNF- $\alpha$ on meniscal repair [25]. In addition, TNF- $\alpha$ had no effect on the migration of meniscal cells after micro-wounding. TNF$\alpha$ treatment of human umbilical vein endothelial cells (HUVECs) caused microtubule bundling [58]; perhaps this reorganization prevents cellular proliferation in response to TNF- $\alpha$. Furthermore, in the presence of serum, TNF- $\alpha$ treatment of inner zone cells suppressed total cell accumulation and proliferation but had no effect on migration, consistent with our explant experiments.

Similar to our results with TGF- $\beta 1$ treatment, in other studies using isolated rabbit meniscal cells cultured in $10 \%$ FBS and equivalent concentrations of TGF- $\beta 1$, there was no effect of TGF $\beta 1$ on cell proliferation at 48 hours [59]. TGF- $\beta 1$ has been shown to increase F-actin levels in isolated chondrocytes [60] and increase actin extensions and lamellar ruffling in agarose embedded chondrocytes [61]. In other studies, 3T3 fibroblasts treated with TGF- $\beta 1$ did not migrate or proliferate and contained stabilized microtubules [62], consistent with the overall effects observed in this study.

In the micro-wounding experiments, overall the responses of the cells at the site of the injury and away from the wound were similar for the different treatments. These data suggest that the effect of the cytokines were stronger than any local factors that may be released in response to the wound. However, IL-1 treatment of outer zone cells and TNF- $\alpha$ treatment of inner cells resulted in differential responses between the cells at the site of the wound and at the edge. In these conditions, local factors produced by the wounded cells [63] may have altered the global response to the cytokine treatment [64], resulting in different responses of the cells at the site of the injury and those away from the wound.

The cellular proliferation measured in meniscal repair model explants in this study is consistent with results from previous studies. In particular, using fresh or frozen meniscal plugs in avascular sheep meniscal injuries treated with $50 \mathrm{ng} / \mathrm{mL}$ TGF- $\beta 1$ for eight weeks also demonstrated no difference in cell density or proliferation but cells further from the tissue surface proliferated in response to TGF- $\beta 1$ [65]. In addition, our data are consistent with an in vivo canine model in which superficial layer cells appeared to be the most active in wound repair of meniscal tissue plugs [29]. Taken together, these results suggest that the superficial cells of the meniscus may be integral in initiating and modulating the repair response.

The decreased cellular proliferation by IL- 1 and TNF- $\alpha$ correlates with the decreased integrative shear strength of repair. In addition, these data are consistent with our previous studies that have shown that IL-1 and TNF- $\alpha$ suppressed integrative meniscal repair and decreased cell accumulation in the repair interface [23,25]. Additionally, the general lack of an effect on cell proliferation in response to TGF- $\beta 1$ treatment is consistent with the mechanical testing data. Previously, we have shown that $1 \mathrm{ng} / \mathrm{mL}$ TGF- $\beta 1$ promoted integrative repair but $10 \mathrm{ng} /$ $\mathrm{mL}$ TGF- $\beta 1$ did not [24]. In adult bovine meniscal repair explants, $10 \mathrm{ng} / \mathrm{mL}$ TGF- $\beta 3$ increased the shear strength of repair at eight weeks but not four weeks [44], suggesting that longer times in culture may be necessary to see the beneficial effects of TGF- $\beta 1$ on meniscal repair. Scaffolds containing TGF- $\beta 3$ increased chemotaxis of cells and articular cartilage regeneration in a rabbit model, as compared to scaffolds without TGF- $\beta 3$ [66], suggesting differential responses of cells to the different isoforms of TGF- $\beta$. Interestingly, the outer zone explants showed increased shear strength of repair in the TNF- $\alpha$ and TGF- $\beta 1$ treatment groups, as compared to inner zone explants. This result is similar to the two-week time point in a previous study, but these differences disappeared over extended culture periods [15].

Cell viability was not altered by any of the treatments in this study, suggesting that the decreased repair in the presence of IL- 1 and TNF- $\alpha$ was not due to induction of cell death by these cytokines. The inner zone control samples stained more strongly for proteoglycans than the outer zone samples, reflecting the intrinsic composition of the meniscal tissue [14]. Histological staining revealed the presence of a predominantly collagen-rich matrix bridging the interface in control and TGF- $\beta 1$ treated samples, whereas reparative tissue was largely absent in IL-1 and TNF- $\alpha$ treated explants. New protein synthesis, in particular collagen deposition [67] and cross-linking $[68,69]$, are required for successful integrative repair in cartilage repair model systems.

While isolated inner and outer zone cells demonstrated different responses to the various treatments, cells of the inner and outer zone meniscal repair model explants exhibited similar responses. Recently, isolated outer zone cells have also been shown to migrate faster and have lower adhesion strength than inner zone cells in response to electric fields [70]. These data suggest that the sub-populations of cells in the meniscus are inherently different but these differences may be masked by the extracellular matrix in explant culture. Isolated cells lack natural cellular morphology and contact with native extracellular matrix components, whereas explants maintain the cells in the context of the extracellular matrix and associated signaling molecules. Important differences have been noted in the ability of cells to move through two-dimensional and threedimensional culture systems, particularly due to the 
barriers presented by collagen networks [71]. In a recent study, fetal, juvenile and adult bovine meniscal cells showed similar proliferation rates and migration abilities in a monolayer micro-wound model. However, fetal and juvenile meniscal repair model explants showed improved repair strength over time while adult explants did not improve [44], further showing the capacity of these two model systems to reveal different information.

These model systems provide valuable information on the cellular response of the meniscus to inflammatory cytokines and growth factors, allowing a careful study of proliferation, migration and matrix deposition under well-controlled environmental conditions. These studies will help to inform future in vivo studies on mechanisms to promote meniscal repair. However, the direct translatability of these studies to in vivo applications is limited by the fact that the joint environment is more complicated, including the presence of many different cell and tissue types and a variety of inflammatory factors that are produced in the joint following meniscal injury. In addition, altered metabolism in all joint tissues and altered mechanical loading effects must be considered for successful in vivo studies.

There are few in vivo meniscal repair studies that have assessed cell migration and proliferation and extracellular matrix deposition. Several animal models of avascular meniscal tears have shown that either autologous or allogenic chondrocytes in a scaffold are necessary for the formation of reparative matrix tissue in the lesion and integration of cells into the native meniscus [72-74]. Animals treated with scaffolds alone resulted in increased cellularity of fibroblast-like cells at the edges of the lesion but no repair tissue in the interface [74]. Adipose-derived mesenchymal stem cells (ASCs) placed in rabbit avascular meniscal lesions prior to suturing, increased the healing rate and yielded an increase in the cellularity of meniscal fibrochondrocytes in the repair tissue [75]. Alternatively, several in vivo studies have demonstrated the need for a vascular supply to promote healing of meniscal lesions, inducing proliferation of vessels, endothelial cells and mesenchymal cells, and resulting in fibrovascular scar tissue repair $[13,76]$. However, proliferation of endothelial cells by vascular endothelial growth factor (VEGF) coated sutures was not sufficient to promote healing of meniscal lesions in the avascular region of sheep menisci [77]. The importance of meniscal cell migration and proliferation in meniscal healing is evidenced by a study showing that donor cells from fresh meniscal allografts in the goat do not survive but the host cells migrate into the allograft and repopulate the transplant [78]. In addition, in canine menisci containing devitalized meniscal plugs, cells migrate across the bridging tissue and into the interface, ultimately migrating into the devitalized plugs, remodeling the matrix, and filling the interface with a hyaline-fibrocartilage matrix [29].

Cell migration and/or proliferation are necessary for endogenous meniscal healing and repair. In order to repair a meniscal tear, cells must repopulate the wound and synthesize new extracellular matrix to achieve integrative repair. However, if cells are not able to fill in the gap, as in the presence of inflammatory cytokines, synthesis of reparative tissue and integrative repair cannot occur. Additionally, IL-1 treatment up-regulates MMP activity that promotes the catabolism of the meniscal extracellular matrix $[24,26,27,34]$. Therefore, a variety of strategies, including blocking proinflammatory cytokines [25], inhibiting MMP activity [26,79], and/or using anabolic growth factors [24] to increase matrix synthesis and promote cellular proliferation, may be required to promote meniscal healing following an injury and to increase the success of tissue engineering constructs.

\section{Conclusions}

In conclusion, we have shown that the inflammatory cytokines IL-1 and TNF- $\alpha$ suppress the proliferation of meniscal cells and suppress integrative meniscal repair, while TGF- $\beta 1$ overall does not alter the proliferation of cells or meniscal repair. In inner zone meniscal cells, migration is increased by IL-1 treatment but not enough to overcome the suppression of proliferation and fill the micro-wound. However, all other factors did not alter cellular migration independent of proliferation. Therefore, the suppression of cellular proliferation by IL-1 and TNF- $\alpha$ may prevent integrative repair of meniscal lesions by decreasing cell accumulation in the wound, and consequently diminishing the available cell population that can mediate the synthesis of reparative tissue. Therefore, strategies that promote the proliferation of meniscal cells may be able to enhance integrative repair following injury and promote the success of tissue engineered constructs.

\section{Abbreviations}

ANOVA: analysis of variance; ASCs: adipose-derived mesenchymal stem cells; BSA: bovine serum albumin; DMEM: Dulbecco's Modified Eagle's Medium; EdU: 5-ethynyl-2'-deoxyuridine; ELF: electroforce; FBS: fetal bovine serum; HEPES: 4-(2-hydroxyethyl)-1-piperazineethanesulfonic acid; HUVEC: human umbilical vein endothelial cells; IL-1: interleukin-1; MMP: matrix

metalloproteinase; NBT: nitroblue tetrazolium chloride; NO: nitric oxide; OA: osteoarthritis; PBS: phosphate buffered saline; PLLA: poly-L-lactide; S-GAG: sulfated glycosaminoglycan; TE: tris ethylenediaminetetraacetic acid; TGF- $\beta 1$ : transforming growth factor-beta 1; TNF-a: tumor necrosis factor-alpha; VEGF: vascular endothelial growth factor.

\section{Acknowledgements}

This study was supported by the Arthritis Foundation, NIH Grants AR50245, AG15768, AR48182, AR48852, and AR55434, and the VA Rehabilitation

Research Service. We thank John Finan for Matlab programming assistance. 
We also thank Robert Nielsen, Kwadwo Owusu-Akyaw, and Karsyn Bailey for technical assistance

\section{Author details}

${ }^{1}$ Department of Orthopaedic Surgery, Duke University Medical Center, DUMC Box 3093, Durham, NC 27710, USA. ²Department of Biomedical Engineering, Duke University, DUMC Box 3093, Durham, NC 27710, USA. ${ }^{3}$ Department of Medicine, Duke University Medical Center, Durham, NC 27705, USA. ${ }^{4}$ Department of Medicine, VA Medical Center, E1006 VA Medical Center, 508 Fulton Street, Durham, NC 27705, USA.

\section{Authors' contributions}

KMR participated in the design of the study, performed the micro-wounding and explant studies, and drafted the manuscript. NER performed the microwounding studies, histology, data analysis and statistical analysis, and helped draft the manuscript. REW wrote the Matlab code and helped with data analysis and manuscript preparation. JBW helped conceive of the study and draft the manuscript. FG helped conceive of the study, participated in the study design and coordination, and helped draft the manuscript. ALM helped conceive of the study, participated in the study design and coordination, performed the micro-wounding experiments, data and statistical analyses, and drafted the manuscript. All authors have read and approved the final manuscript.

\section{Competing interests}

The authors declare that they have no competing interests.

Received: 26 September 2011 Revised: 8 November 2011

Accepted: 16 November 2011 Published: 16 November 2011

\section{References}

1. Ahmed AM, Burke DL: In-vitro measurement of static pressure distribution in synovial joints-Part I: Tibial surface of the knee. J Biomech Eng 1983, 105:216-225

2. Markolf KL, Bargar WL, Shoemaker SC, Amstutz HC: The role of joint load in knee stability. J Bone Joint Surg Am 1981, 63:570-585.

3. Arnoczky S, McDevitt C: The meniscus: structure, function, repair, and replacement. In Orthopaedic Basic Science. Edited by: Buckwalter J, Einhorn T, Simon S. Rosemont, IL: American Academy of Orthopaedic Surgeons; 2000:531-545.

4. Wojtys EM, Chan DB: Meniscus structure and function. AAOS Instructional Course Lectures 2005, 54:323-330.

5. Majewski M, Susanne H, Klaus S: Epidemiology of athletic knee injuries: a10-year study. Knee 2006, 13:184-188.

6. Christoforakis J, Pradhan R, Sanchez-Ballester J, Hunt N, Strachan RK: Is there an association between articular cartilage changes and degenerative meniscus tears? Arthroscopy 2005, 21:1366-1369.

7. Hunter DJ, Zhang YQ, Niu JB, Tu X, Amin S, Clancy M, Guermazi A, Grigorian M, Gale D, Felson DT: The association of meniscal pathologic changes with cartilage loss in symptomatic knee osteoarthritis. Arthritis Rheum 2006, 54:795-801.

8. Roos H, Lauren M, Adalberth T, Roos EM, Jonsson K, Lohmander LS: Knee osteoarthritis after meniscectomy: prevalence of radiographic changes after twenty-one years, compared with matched controls. Arthritis Rheum $1998,41: 687-693$.

9. Wyland DJ, Guilak F, Elliott DM, Setton LA, Vail TP: Chondropathy after meniscal tear or partial meniscectomy in a canine model. J Orthop Res 2002, 20:996-1002.

10. Berthiaume MJ, Raynauld JP, Martel-Pelletier J, Labonte F, Beaudoin G, Bloch DA, Choquette D, Haraoui B, Altman RD, Hochberg M, Meyer JM, Cline GA, Pelletier JP: Meniscal tear and extrusion are strongly associated with progression of symptomatic knee osteoarthritis as assessed by quantitative magnetic resonance imaging. Ann Rheum Dis 2005 64:556-563.

11. Sharma L, Eckstein F, Song J, Guermazi A, Prasad P, Kapoor D, Cahue S, Marshall M, Hudelmaier M, Dunlop D: Relationship of meniscal damage, meniscal extrusion, malalignment, and joint laxity to subsequent cartilage loss in osteoarthritic knees. Arthritis Rheum 2008, 58:1716-1726.

12. Lohmander LS, Roos H, Dahlberg L, Hoerrner LA, Lark MW: Temporal patterns of stromelysin-1, tissue inhibitor, and proteoglycan fragments in human knee joint fluid after injury to the cruciate ligament or meniscus. J Orthop Res 1994, 12:21-28.

13. Arnoczky SP, Warren RF: The microvasculature of the meniscus and its response to injury. An experimental study in the dog. Am J Sports Med 1983, 11:131-141.

14. Arnoczky SP, Warren RF: Microvasculature of the human meniscus. Am J Sports Med 1982, 10:90-95.

15. Hennerbichler A, Moutos FT, Hennerbichler D, Weinberg JB, Guilak F: Repair response of the inner and outer regions of the porcine meniscus in vitro. Am J Sports Med 2007, 35:754-762.

16. Hellio Le Graverand MP, Ou Y, Schield-Yee T, Barclay L, Hart D, Natsume T, Rattner JB: The cells of the rabbit meniscus: their arrangement, interrelationship, morphological variations and cytoarchitecture. J Anat 2001, 198:525-535.

17. Upton ML, Chen J, Setton LA: Region-specific constitutive gene expression in the adult porcine meniscus. J Orthop Res 2006, 24:1562-1570.

18. Cheung HS: Distribution of type I, II, III and V in the pepsin solubilized collagens in bovine menisci. Connect Tissue Res 1987, 16:343-356.

19. Eyre DR, Muir H: The distribution of different molecular species of collagen in fibrous, elastic and hyaline cartilages of the pig. Biochem J 1975, 151:595-602.

20. Kambic HE, McDevitt CA: Spatial organization of types I and II collagen in the canine meniscus. J Orthop Res 2005, 23:142-149.

21. Kobayashi K, Fujimoto E, Deie M, Sumen Y, Ikuta Y, Ochi M: Regional differences in the healing potential of the meniscus-an organ culture model to eliminate the influence of microvasculature and the synovium. Knee 2004, 11:271-278.

22. Kawamura S, Lotito K, Rodeo SA: Biomechanics and healing response of the meniscus. Operative Techniques Sports Med 2003, 11:68-76.

23. Hennerbichler A, Moutos FT, Hennerbichler D, Weinberg JB, Guilak F: Interleukin-1 and tumor necrosis factor alpha inhibit repair of the porcine meniscus in vitro. Osteoarthritis Cartilage 2007, 15:1053-1060.

24. McNulty AL, Guilak F: Integrative repair of the meniscus: lessons from in vitro studies. Biorheology 2008, 45:487-500.

25. McNulty AL, Moutos FT, Weinberg JB, Guilak F: Enhanced integrative repai of the porcine meniscus in vitro by inhibition of interleukin-1 or tumor necrosis factor alpha. Arthritis Rheum 2007, 56:3033-3042.

26. McNulty AL, Weinberg JB, Guilak F: Inhibition of matrix metalloproteinases enhances in vitro repair of the meniscus. Clin Orthop Relat Res 2009, 467:1557-1567.

27. Wilusz RE, Weinberg JB, Guilak F, McNulty AL: Inhibition of integrative repair of the meniscus following acute exposure to interleukin-1 in vitro. J Orthop Res 2008, 26:504-512.

28. Arnoczky SP, Warren RF, Spivak JM: Meniscal repair using an exogenous fibrin clot. An experimental study in dogs. J Bone Joint Surg Am 1988, 70:1209-1217.

29. Kambic HE, Futani H, McDevitt CA: Cell, matrix changes and alpha-smooth muscle actin expression in repair of the canine meniscus. Wound Repair Regen 2000, 8:554-561.

30. Lotz M: Cytokines in cartilage injury and repair. Clin Orthop Relat Res 2001, 391:S108-115.

31. Fernandes JC, Martel-Pelletier J, Pelletier JP: The role of cytokines in osteoarthritis pathophysiology. Biorheology 2002, 39:237-246.

32. Kahle P, Saal JG, Schaudt K, Zacher J, Fritz P, Pawelec G: Determination of cytokines in synovial fluids: correlation with diagnosis and histomorphological characteristics of synovial tissue. Ann Rheum Dis 1992, 51:731-734.

33. Hopkins SJ, Humphreys M, Jayson Ml: Cytokines in synovial fluid. I. The presence of biologically active and immunoreactive IL-1. Clin Exp Immunol 1988, 72:422-427.

34. McNulty AL, Estes BT, Wilusz RE, Weinberg JB, Guilak F: Dynamic loading enhances integrative meniscal repair in the presence of interleukin-1. Osteoarthritis Cartilage 2010, 18:830-838.

35. Lotz M, Blanco FJ, von Kempis J, Dudler J, Maier R, Villiger PM, Geng Y: Cytokine regulation of chondrocyte functions. J Rheumatol Supp/ 1995, 43:104-108.

36. van den Berg WB, Joosten LA, van de Loo FA: TNF alpha and IL-1 beta are separate targets in chronic arthritis. Clin Exp Rheumatol 1999, 17(6 Suppl 18):S105-114. 
37. Shin SJ, Fermor B, Weinberg JB, Pisetsky DS, Guilak F: Regulation of matrix turnover in meniscal explants: role of mechanical stress, interleukin-1, and nitric oxide. J Appl Physiol 2003, 95:308-313.

38. Bhargava MM, Attia ET, Murrell GA, Dolan MM, Warren RF, Hannafin JA: The effect of cytokines on the proliferation and migration of bovine meniscal cells. Am J Sports Med 1999, 27:636-643.

39. Pangborn CA, Athanasiou KA: Effects of growth factors on meniscal fibrochondrocytes. Tissue Eng 2005, 11:1141-1148.

40. Gunja NJ, Uthamanthil RK, Athanasiou KA: Effects of TGF-beta1 and hydrostatic pressure on meniscus cell-seeded scaffolds. Biomaterials 2009, 30:565-573.

41. Collier S, Ghosh P: Effects of transforming growth factor beta on proteoglycan synthesis by cell and explant cultures derived from the knee joint meniscus. Osteoarthritis Cartilage 1995, 3:127-138.

42. Stewart K, Pabbruwe M, Dickinson S, Sims T, Hollander AP, Chaudhuri JB: The effect of growth factor treatment on meniscal chondrocyte proliferation and differentiation on polyglycolic acid scaffolds. Tissue Eng 2007, 13:271-280.

43. Gruber HE, Mauerhan D, Chow Y, Ingram JA, Norton HJ, Hanley EN Jr, Sun Y: Three-dimensional culture of human meniscal cells: extracellular matrix and proteoglycan production. BMC Biotechnol 2008, 8:54.

44. Ionescu LC, Lee GC, Garcia GH, Zachry TL, Shah RP, Sennett BJ, Mauck RL: Maturation state-dependent alterations in meniscus integration: implications for scaffold design and tissue engineering. Tissue Eng: Part A 2011, 17:193-203.

45. Steinert AF, Palmer GD, Capito R, Hofstaetter JG, Pilapil C, Ghivizzani SC, Spector $\mathrm{M}$, Evans $\mathrm{CH}$ : Genetically enhanced engineering of meniscus tissue using ex vivo delivery of transforming growth factor-b1 complementary deoxyribonucleic acid. Tissue Eng 2007, 13:2227-2237.

46. Fermor B, Jeffcoat D, Hennerbichler A, Pisetsky DS, Weinberg JB, Guilak F: The effects of cyclic mechanical strain and tumor necrosis factor alpha on the response of cells of the meniscus. Osteoarthritis Cartilage 2004, 12:956-962.

47. Basile P, Dadali T, Jacobson J, Hasslund S, Ulrich-Vinther M, Soballe K, Nishio Y, Drissi MH, Langstein HN, Mitten DJ, O'Keefe RJ, Schwarz EM, Awad HA: Freeze-dried tendon allografts as tissue-engineering scaffolds for Gdf5 gene delivery. Mol Ther 2008, 16:466-473.

48. Hocking DC, Chang $\mathrm{CH}$ : Fibronectin matrix polymerization regulates small airway epithelial cell migration. Am J Physiol Lung Cell Mol Physiol 2003, 285:L169-179.

49. Maffulli N, Ewen SW, Waterston SW, Reaper J, Barrass V: Tenocytes from ruptured and tendinopathic achilles tendons produce greater quantities of type III collagen than tenocytes from normal achilles tendons. An in vitro model of human tendon healing. Am J Sports Med 2000, 28:499-505.

50. Hembree WC, Ward BD, Furman BD, Zura RD, Nichols LA, Guilak F, Olson SA: Viability and apoptosis of human chondrocytes in osteochondral fragments following joint trauma. J Bone Joint Surg $\mathrm{Br}$ 2007, 89:1388-1395.

51. Lewis JS, Hembree WC, Furman BD, Tippets L, Cattel D, Huebner JL, Little D, DeFrate LE, Kraus VB, Guilak F, Olson SA: Acute joint pathology and synovial inflammation is associated with increased intra-articular fracture severity in the mouse knee. Osteoarthritis Cartilage 2011, 19:864-873.

52. Lewis $J$, Deloria LB, Oyen-Tiesma M, Thompson RC Jr, Ericson M, Oegema TR Jr: Cell death after cartilage impact occurs around matrix cracks. J Orthop Res 2003, 21:881-887.

53. Ronot X, Sene C, Boschetti E, Hartmann DJ, Adolphe M: Culture of chondrocytes in medium supplemented with fetal calf serum or a serum substitute: Ultroser G. Biol Cell 1984, 51:307-313.

54. Frenkel SR, Clancy RM, Ricci JL, Di Cesare PE, Rediske JJ, Abramson SB: Effects of nitric oxide on chondrocyte migration, adhesion, and cytoskeletal assembly. Arthritis Rheum 1996, 39:1905-1912.

55. O'Keefe RJ, Puzas JE, Brand JS, Rosier RN: Effect of transforming growth factor-beta on DNA synthesis by growth plate chondrocytes: modulation by factors present in serum. Calcif Tissue Int 1988, 43:352-358.

56. Pritchard S, Guilak F: Effects of interleukin-1 on calcium signaling and the increase of filamentous actin in isolated and in situ articular chondrocytes. Arthritis Rheum 2006, 54:2164-2174.
57. Qi J, Fox AM, Alexopoulos LG, Chi L, Bynum D, Guilak F, Banes AJ: IL-1beta decreases the elastic modulus of human tenocytes. J Appl Physiol 2006, 101:189-195

58. Molony L, Armstrong L: Cytoskeletal reorganizations in human umbilical vein endothelial cells as a result of cytokine exposure. Exp Cell Res 1991, 196:40-48.

59. Kasemkijwattana C, Menetrey J, Goto H, Niyibizi C, Fu FH, Huard J: The use of growth factors, gene therapy and tissue engineering to improve meniscal healing. Mater Sci Eng C - Biomimetic Supramol Syst 2000, 13:19-28.

60. Leipzig ND, Eleswarapu SV, Athanasiou KA: The effects of TGF-beta1 and IGF-I on the biomechanics and cytoskeleton of single chondrocytes. Osteoarthritis Cartilage 2006, 14:1227-1236.

61. Haudenschild DR, Chen J, Steklov N, Lotz MK, D'Lima DD: Characterization of the chondrocyte actin cytoskeleton in living three-dimensional culture: response to anabolic and catabolic stimuli. Mol Cell Biomech 2009, 6:135-144.

62. Gundersen GG, Kim I, Chapin CJ: Induction of stable microtubules in $3 \mathrm{T3}$ fibroblasts by TGF-beta and serum. J Cell Sci 1994, 107:645-659.

63. Li J, Chen J, Kirsner R: Pathophysiology of acute wound healing. Clin Dermatol 2007, 25:9-18.

64. Li D, Zhang C, Song F, Lubenec I, Tian Y, Song QH: VEGF regulates FGF-2 and TGF-beta1 expression in injury endothelial cells and mediates smooth muscle cells proliferation and migration. Microvasc Res 2009, 77:134-142.

65. Izal I, Ripalda P, Acosta CA, Forriol F: In vitro healing of avascular meniscal injuries with fresh and frozen plugs treated with TGF-beta1 and IGF-1 in sheep. Int J Clin Exp Pathol 2008, 1:426-434.

66. Mao JJ, Lee CH, Cook JL, Mendelson A, Moioli EK, Yao H: Regeneration of the articular surface of the rabbit synovial joint by cell homing: a proof of concept study. Lancet 2010, 376:440-448.

67. DiMicco MA, Sah RL: Integrative cartilage repair: adhesive strength is correlated with collagen deposition. J Orthop Res 2001, 19:1105-1112.

68. DiMicco MA, Waters SN, Akeson WH, Sah RL: Integrative articular cartilage repair: dependence on developmental stage and collagen metabolism. Osteoarthritis Cartilage 2002, 10:218-225.

69. Ahsan T, Lottman LM, Harwood F, Amiel D, Sah RL: Integrative cartilage repair: inhibition of B-aminopropionitrile. J Orthop Res 1999, 17:850-857.

70. Gunja NJ, Dujari D, Chen A, Luengo A, Fong JV, Hung CT: Migration responses of outer and inner meniscus cells to applied direct current electric fields. J Orthop Res 2011, 30:103-111.

71. Morales TI: Chondrocyte moves: clever strategies? Osteoarthritis Cartilage 2007, 15:861-871.

72. Weinand C, Peretti GM, Adams SB Jr, Bonassar LJ, Randolph MA, Gill TJ: An allogenic cell-based implant for meniscal lesions. Am J Sports Med 2006, 34:1779-1789.

73. Weinand C, Peretti GM, Adams SB Jr, Randolph MA, Savvidis E, Gill TJ: Healing potential of transplanted allogeneic chondrocytes of three different sources in lesions of the avascular zone of the meniscus: a pilot study. Arch Orthop Trauma Surg 2006, 126:599-605.

74. Peretti GM, Gill TJ, Xu JW, Randolph MA, Morse KR, Zaleske DJ: Cell-based therapy for meniscal repair: a large animal study. Am J Sports Med 2004 32:146-158.

75. Ruiz-Iban MA, Diaz-Heredia J, Garcia-Gomez I, Gonzalez-Lizan F, EliasMartin E, Abraira V: The effect of the addition of adipose-derived mesenchymal stem cells to a meniscal repair in the avascular zone: an experimental study in rabbits. Arthroscopy 2011.

76. Becker R, Pufe T, Kulow S, Giessmann N, Neumann W, Mentlein R, Petersen W: Expression of vascular endothelial growth factor during healing of the meniscus in a rabbit model. J Bone Joint Surg Br 2004, 86:1082-1087.

77. Petersen W, Pufe T, Starke C, Fuchs T, Kopf S, Neumann W, Zantop T, Paletta J, Raschke M, Becker R: The effect of locally applied vascular endothelial growth factor on meniscus healing: gross and histological findings. Arch Orthop Trauma Surg 2007, 127:235-240.

78. Jackson DW, Whelan J, Simon TM: Cell survival after transplantation of fresh meniscal allografts. DNA probe analysis in a goat model. Am J Sports Med 1993, 21:540-550. 
79. Wilson CG, Vanderploeg EJ, Zuo F, Sandy JD, Levenston ME:

Aggrecanolysis and in vitro matrix degradation in the immature bovine meniscus: mechanisms and functional implications. Arthritis Res Ther 2009, 11:R173.

doi:

Cite this article as: Riera et al:: Interleukin-1, tumor necrosis factor-alpha, and transforming growth factor-beta 1 and integrative meniscal repair: influences on meniscal cell proliferation and migration. Arthritis Research \& Therapy 2011 13:R187.

Submit your next manuscript to BioMed Central and take full advantage of:

- Convenient online submission

- Thorough peer review

- No space constraints or color figure charges

- Immediate publication on acceptance

- Inclusion in PubMed, CAS, Scopus and Google Scholar

- Research which is freely available for redistribution

Submit your manuscript at www.biomedcentral.com/submit
C Biomed Central 